Review Article

\title{
Green Supplier Evaluation and Selections: A State-of-the-Art Literature Review of Models, Methods, and Applications
}

\author{
Li-Jun Zhang, ${ }^{1}$ Ran Liu, ${ }^{1}$ Hu-Chen Liu $\mathbb{D}^{2,3}$ and Hua Shi ${ }^{1}{ }^{1}$ \\ ${ }^{1}$ School of Management, Shanghai University, Shanghai 200444, China \\ ${ }^{2}$ School of Economics and Management, Tongji University, Shanghai 200092, China \\ ${ }^{3}$ College of Economics and Management, China Jiliang University, Hangzhou 310018, China \\ Correspondence should be addressed to Hu-Chen Liu; huchenliu@foxmail.com
}

Received 25 January 2020; Revised 22 May 2020; Accepted 15 June 2020; Published 15 July 2020

Academic Editor: Ramon Sancibrian

Copyright (c) 2020 Li-Jun Zhang et al. This is an open access article distributed under the Creative Commons Attribution License, which permits unrestricted use, distribution, and reproduction in any medium, provided the original work is properly cited.

\begin{abstract}
The role of green supplier evaluation and selection (GSES) in supply chain management is increasingly appreciated due to the intensification of competition, raising public consciousness, and environmental issues. To improve GSES, a large number of approaches have been proposed in the past decades. However, few attempts have been made to systematically review and classify the literature in this field. The objective of this study is to afford a comprehensive review of the studies which aim to develop models and methods in helping enterprises to assess and select the right green suppliers. To achieve this goal, a total of 193 journal articles extracted from the Scopus database over the period of 2009 to 2020 were chosen and reviewed. These publications were classified into ten categories based on their adopted GSES models and analyzed concerning the evaluation criteria, criteria weighting methods, and performance evaluation methods. Moreover, a bibliometric analysis was conducted according to the frequency of supplier selection methods, citation number, publication year, journal, country, and application area. This study supports practitioners, managers, and researchers in effectively recognizing and applying the GSES models to enhance organizational competitiveness and provides an insight into its state of the art.
\end{abstract}

\section{Introduction}

Nowadays, the intensification of competition, stringent government laws, and increasing environmental issues have forced enterprises to improve sustainable outcomes in their operation and supply chain practices. Achieving sustainability needs the integration of environmental, social, and economic attributes into their manufacturing processes and supply chains [1]. Supply chains are sophisticated, composed of different organizations dispersed across multiple tiers and different geographies [2]. Green supply chain management (GSCM) is an enterprise strategy which integrates environmental thinking into the supply chain management $[3,4]$. In GSCM, complicated mechanisms were employed to the integration and factory level to appraise or enhance environmental outcomes [5]. Via the association among suppliers and consumers, manufacturers could build and practice a compelling arrangement programme while confronting environmental challenges. The implementation of green supply chain can reduce the generation of pollutants from the source, and the greening degree of suppliers will directly affect the environmental performance of firms $[6,7]$. In addition, implementing the green supply chain can bring economic benefits and competitive advantages to a firm, which is paramount important to the development of the firm [8].

Since GSCM includes different phases from raw material purchase to the final product delivery, a focal company should not only green the intraorganizational supply chain operations but also focus on the interorganizational aspects. Suppliers, as upstream supply chain partners, play a significant role in the achievement of sustainability objectives of a firm. Thus, selecting the most qualified green supplier in a supply chain is a vital strategic decision to maintain the competitive position of an organization internationally $[5,6]$. For the purpose of high quality and environmental 
standards, various aspects and criteria are needed to be considered in the green supplier selection. So, green supplier selection can be seen as a challenging decision-making problem with the goal of ensuring better performance from an enterprise's suppliers.

In the past few years, the development of practical green supplier evaluation and selection (GSES) methods is rapidly evolving $[7,8]$. Some literature reviews on GSCM or green supplier selection have been conducted in prior studies from different aspects. For instance, Koberg and Longoni [2] proposed a systematic literature review of the papers focused on GSCM in global supply chains. Badi and Murtagh [9] performed a systematic review of the literature on GSCM in the construction industry. Bastas and Liyanage [1] undertook a literature review on the integration of quality management, supply chain management, and sustainability management. Maditati et al. [3] investigated the relationships among GSCM drivers, practice indicators, and performance measures via a bibliometric analysis of GSCM articles. Fang and Zhang [10] explored the overall relationship between GSCM practice and company performance by a meta-analysis of the GSCM literature. Fahimnia et al. [4] analyzed the published studies related to GSCM with the aid of bibliometric and network analysis tools. Mardani et al. [11] presented a systematic review of the application of structural equation modelling in the assessment of sustainable and green supply chain management. Igarashi et al. [12] provided a literature review on supplier selection and proposed a conceptual model to integrate the different dimensions of green supplier selection. Konys [13] conducted a meta-analysis of the literature on green-oriented supplier selection and introduced an ontology-based method to synthetize the analyzed selection and evaluation criteria of suppliers. In addition, the quantitative and qualitative decision methodologies in sustainable supplier management were reviewed and analyzed in [7], the multicriteria decision-making (MCDM) methods for designing green supply chains were reviewed in [14], and the MCDM approaches for evaluating green supplier performance were analyzed in [15].

Although the existing literature on GSCM is extensive, no or few research studies have been conducted to review the mathematical models used for supporting GSES comprehensively. The reviews $[14,15]$ only focused on the MCDM models for green supplier selection, and a previous study by Zimmer et al. [7] does not report criteria weighting methods and performance evaluation methods. Moreover, these literature surveys need an update since more than half of all related papers have been published after their analysis. Therefore, in this study, we systematically review the scientific literature related to GSES models by using the academic database of Scopus. Following a methodological review process, a total of 193 journal articles published between 2009 and 2020 were identified. The main aim of this study is to solve the following research questions: (1) What GSES methodologies have been developed in the literature? (2) What are the criteria considered for GSES problems? (3) What are the weighting methods used for deriving criteria weights? (4) What are the uncertainty methods adopted for managing experts' evaluation information? Moreover, the statistical analyses on year, journal, country, and application area have been analyzed in order to provide a roadmap to researchers studied in this field.

The rest of this study is organized as follows. After Section 1, Section 2 describes the research methodology followed for the literature review. Section 3 conducts a detailed review of the selected articles classified into ten categories. The bibliometric analysis results and future research suggestions are presented in Sections 4 and 5, respectively. Finally, we conclude this paper in Section 6.

\section{Research Methodology}

To perform a systematic review on the literature of green supplier evaluation and selection, we here followed the PRISMA method [16]. The PRISMA method mainly includes three stages: literature search, eligible article selection, and data extraction. First, the electronic database of Scopus was used for literature search since it is the largest abstract and citation database of the peer-reviewed literature, allowing in-depth exploration of the literature. Only articles written in English and published in academic peer-reviewed journals are considered in this review study. The literature search was conducted by searching the keywords "green supplier selection" and "sustainable supplier selection" in the title, abstract, or keywords for identifying pertinent papers comprehensively. In addition, the time span of this literature review is limited to 2009-2020, and the search was completed in May 2020. As a consequence, a total of 501 papers were retrieved in line with the search strategy as described above. In the second stage, we choose the scientific literature which is in line with the scope of this review. This study only centers on the research studies which had proposed a method or model to address green supplier evaluation and selection problems. Conversely, those papers that research the actual practices of green purchasing and green procurement or only include the environmental performance in supplier selection without quantitative analysis were omitted in the review. Eventually, 193 relevant papers were selected after title $(n=318)$, abstract $(n=281)$, and full-text screening $(n=193)$ based on our inclusion criteria. In the third stage, necessary data were collected from the 193 papers, and the included scholarly researches were summarized (Section 3) and analyzed based on, e.g., supplier selection model, publication year, and published journal (Section 4). Figure 1 illustrates the entire review procedure of this literature survey. It may be mentioned that this literature review was performed very carefully and presents a comprehensive basis regarding the models, methods, and applications of green supplier evaluation and selection.

\section{Green Supplier Evaluation and Selection Methods}

From the collected literature, we can find that multifarious models and methods have been proposed and used to handle the GSES problems. Based on the methods employed in determining the ranking of candidate green suppliers, we 


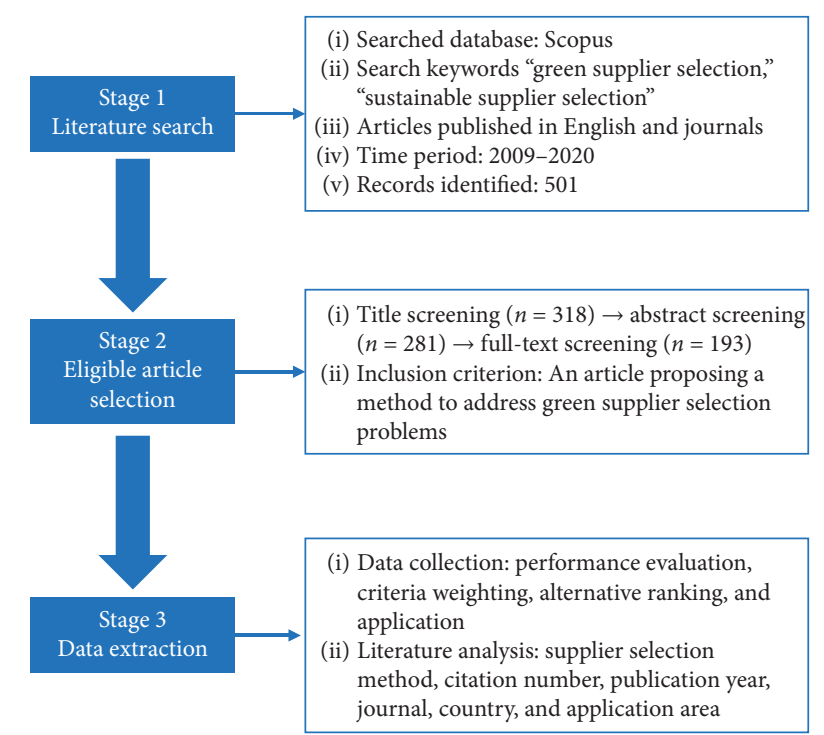

FIgURE 1: Article review process based on the PRISMA method.

construct a classification framework to segregate the literature of the topic to be studied. According to the classification framework, the identified 193 articles are classified into ten categories, including distance-based methods, compromise methods, outranking methods, pairwise comparison methods, mathematical programming methods, aggregation operator-based methods, value and utility methods, combined methods, other green supplier selection methods, and supplier selection and order allocation (SSOA) methods. The categories with their related GSES approaches and papers are summarized in Table 1 . Note that the value in the parenthesis denotes the number of articles included in the category.

In the following sections, each of the ten categories is focused and the relevant literature is reviewed in detail with focus on the approaches adopted for green supplier evaluation and selection.

3.1. Distance-Based Methods. First, 31 articles were identified to employ the distance-based methods for GSES. Gupta and Barua [17] proposed a hybrid methodology comprising the best worst method (BWM) and the fuzzy technique for the order of preference by similarity to an ideal solution (TOPSIS) for selecting suppliers among small and medium enterprises based on their green innovation ability. Tian et al. [18] applied an intuitionistic fuzzy TOPSIS method integrated with BWM for green supplier selection, and Yucesan et al. [19] combined the BWM with an interval type-2 fuzzy TOPSIS method to solve green supplier selection problems. Wang Chen et al. [20] developed an integrated fuzzy analytic hierarchy process (AHP)-TOPSIS approach for green supplier selection. Abdel-Basset et al. [21] presented an integrated interval-valued neutrosophic analytical network process (ANP)-TOPSIS framework to deal with sustainable supplier selection problems. Some researches selected the most suitable supplier regarding the environmental competencies by using the fuzzy TOPSIS [25, 26], the intuitionistic fuzzy TOPSIS [23, 24], and the interval type-2 fuzzy TOPSIS [22] methods.

dos Santos et al. [28] integrated fuzzy TOPSIS with the entropy method for the evaluation and selection of green suppliers; Yu et al. [27] utilized an entropy-based TOPSIS method for sustainable supplier selection in the intervalvalued Pythagorean fuzzy context. In [35], a hesitant fuzzy TOPSIS model is constructed for supplier evaluation in the green supply chain, in which the evaluation criteria were determined by the decision-making trial and evaluation laboratory model (DEMATEL), and the criteria weights were obtained using the maximizing deviation method. In [36], a hybrid MCDM approach based on the DEMATEL, ANP, and fuzzy TOPSIS was introduced to evaluate green suppliers in fuzzy environment. In [37], a hybrid roughfuzzy DEMATEL-TOPSIS method was proposed for sustainable supplier selection for a smart supply chain. Fallahpour et al. [30] utilized a hybrid model based on fuzzy preference programming and fuzzy TOPSIS for sustainable supplier selection in a textile company, and Van et al. [29] adopted an integrated approach based on quality function deployment (QFD) and interval neutrosophic TOPSIS for green supplier evaluation in a transportation parts company. Besides, different combination weighting methods (i.e., AHP + entropy method, expert judgement + entropy method, expert judgement + maximizing distance method, and expert judgement + statistical variance method) have been combined with the TOPSIS [32], the fuzzy TOPSIS [34], the intuitionistic fuzzy TOPSIS [33], and the rough cloud TOPSIS [31], respectively, for selecting the best green supplier.

In [41], an integrated green supplier selection approach was proposed with ANP and an improved grey relational analysis (GRA). In [39], an enhanced hybrid GRA model was presented for green resilient supply chain network assessment. A GRA-based green supplier selection method was suggested in [38] that incorporates BWM and fuzzy grey cognitive map to assign criteria weights. Tseng and Chiu [42] applied the fuzzy GRA approach for evaluating firm's green supply chain management in linguistic preferences, and Tseng [43] utilized fuzzy set theory with grey degree for green supplier selection with linguistic preferences and incomplete information. A weighted grey incidence decision approach was developed by Quan et al. [40] to evaluate and choose the best green supplier in the process industry.

Based on the EDAS method, Yazdani et al. [44] developed a hybrid decision-making model to deal with the GSES problem of a construction company under legislation and risk factors. In this study, the DEMATEL method was employed to calculate the weight of each evaluation criterion, and the failure mode and effect analysis (FMEA) technique was used to determine the risk rating of each alternative supplier. Xu et al. [45] established an extended EDAS model with single-valued complex neutrosophic sets and applied it for green supplier selection. $\mathrm{Xu}$ et al. [46] developed a GSES model through the combination of heterogeneous criteria information and an extended multiattributive border approximation area comparison (MABAC) method. A soft computing approach based on 
TABLE 1: GSES methods used in the reviewed literature.

\begin{tabular}{|c|c|c|c|}
\hline Classification & GSES method & Reference & Frequency \\
\hline \multirow{5}{*}{ Distance-based methods (31) } & TOPSIS & {$[17-37]$} & 21 \\
\hline & GRA & {$[38-43]$} & 6 \\
\hline & EDAS & {$[44,45]$} & 2 \\
\hline & MABAC & [46] & 1 \\
\hline & Relative-closeness coefficient & {$[47]$} & 1 \\
\hline \multirow{2}{*}{ Compromise methods (19) } & VIKOR & {$[48-61]$} & 14 \\
\hline & MULTIMOORA & {$[62-66]$} & 5 \\
\hline \multirow{3}{*}{ Outranking methods (14) } & ELECTRE & {$[67-72]$} & 6 \\
\hline & PROMETHEE & {$[73-76]$} & 4 \\
\hline & QUALIFLEX & {$[77-80]$} & 4 \\
\hline \multirow{3}{*}{ Pairwise comparison methods (11) } & AHP & {$[81-85]$} & 5 \\
\hline & ANP & {$[86-90]$} & 5 \\
\hline & AQM & [91] & 1 \\
\hline \multirow{2}{*}{ Mathematical programming methods (22) } & $D E A$ & {$[92-109]$} & 18 \\
\hline & MOLP & {$[110-113]$} & 4 \\
\hline \multirow{15}{*}{ Value and utility methods (30) } & TODIM & [114-119] & 6 \\
\hline & Prospect theory & {$[120-122]$} & 3 \\
\hline & Axiomatic design method & {$[123-125]$} & 3 \\
\hline & Possibilistic statistical method & {$[126-128]$} & 3 \\
\hline & Digraph and matrix method & {$[128,129]$} & 2 \\
\hline & WASPAS & {$[130-132]$} & 3 \\
\hline & COPRAS & {$[133,134]$} & 2 \\
\hline & MAUT & [135] & 1 \\
\hline & MARCOS & {$[136]$} & 1 \\
\hline & Range of value & {$[137]$} & 1 \\
\hline & Possibility degree & {$[138]$} & 1 \\
\hline & Fuzzy comprehensive evaluation & {$[139]$} & 1 \\
\hline & Fuzzy performance index & {$[140]$} & 1 \\
\hline & Fuzzy preference relationship & {$[141]$} & 1 \\
\hline & Piecewise linear value function & {$[142]$} & 1 \\
\hline \multirow{9}{*}{ Aggregation operator-based methods (12) } & Choquet integral & [143-146] & 4 \\
\hline & Hybrid aggregation operator & [147] & 1 \\
\hline & Prioritized average operator & {$[148]$} & 1 \\
\hline & PBM operator & {$[149]$} & 1 \\
\hline & HFHPWA operator & {$[150]$} & 1 \\
\hline & IVIFGWHM operator & {$[151]$} & 1 \\
\hline & FWA operator & {$[152]$} & 1 \\
\hline & TOWA operator & {$[153]$} & 1 \\
\hline & SVTNDPNBM operator & {$[154]$} & 1 \\
\hline \multirow{13}{*}{ Combined supplier selection methods (14) } & GRA-TOPSIS & {$[155,156]$} & 2 \\
\hline & TOPSIS, MOORA, GRA & [157] & 1 \\
\hline & TOPSIS, VIKOR, GRA & {$[158]$} & 1 \\
\hline & MOORA, COPRAS & {$[159]$} & 1 \\
\hline & MOORA, WASPAS & {$[160]$} & 1 \\
\hline & MLMCDM, TOPSIS & {$[161]$} & 1 \\
\hline & AHP, TOPSIS, IRP & {$[162]$} & 1 \\
\hline & VIKOR, ELECTRE & {$[163]$} & 1 \\
\hline & ARAS, MOLP & {$[164]$} & 1 \\
\hline & TOPSIS, ELECTRE & {$[165]$} & 1 \\
\hline & TOPSIS, TODIM & {$[166]$} & 1 \\
\hline & TOPSIS, ANFIS & {$[167]$} & 1 \\
\hline & TOPSIS, FIS & {$[168]$} & 1 \\
\hline
\end{tabular}


TABLE 1: Continued.

\begin{tabular}{|c|c|c|c|}
\hline Classification & GSES method & Reference & Frequency \\
\hline \multirow{8}{*}{ Other supplier selection methods (9) } & Bayesian network, genetic algorithm & [169] & 1 \\
\hline & Bayesian framework, Monte Carlo Markov chain & {$[170]$} & 1 \\
\hline & Systems dynamics & [171] & 1 \\
\hline & FIS & {$[172,173]$} & 2 \\
\hline & Satisfaction degree framework, regret theory & [174] & 1 \\
\hline & Consensus decision-making method & {$[175]$} & 1 \\
\hline & Decision-theoretic rough set & {$[176]$} & 1 \\
\hline & Six sigma quality indices & {$[177]$} & 1 \\
\hline \multirow{10}{*}{ Supplier selection and order allocation methods (31) } & TOPSIS, MOLP & {$[178-188]$} & 11 \\
\hline & AHP, MOLP & {$[189-192]$} & 4 \\
\hline & GRA, MOLP & [193] & 1 \\
\hline & BWM, MOLP & {$[194]$} & 1 \\
\hline & QFD, MOLP & [195] & 1 \\
\hline & MOORA, FMEA, MOLP & {$[196]$} & 1 \\
\hline & Decision field theory, MOLP & [197] & 1 \\
\hline & AQM, MOLP & [198] & 1 \\
\hline & DEMATEL, Taguchi loss function, MOLP & [199] & 1 \\
\hline & MOLP model & {$[200-208]$} & 9 \\
\hline
\end{tabular}

interval type- 2 trapezoidal fuzzy sets and relative-closeness coefficients was presented in [47] for the green supplier selection problem.

3.2. Compromise Methods. Nineteen articles in our reviewed literature apply the compromise methods to handle GSES problems. First, the interval-valued fuzzy VIKOR (VlseKriterijumska Optimizacija I Kompromisno Resenje) [49], the picture fuzzy VIKOR $[56,61]$, and the interval-valued intuitionistic fuzzy VIKOR [57] were proposed to evaluate and select the best supplier in sustainable supplier management. In [48], a green supplier selection method based on BWM and VIKOR was introduced to address the GSES problem in interval type-2 fuzzy environment; in [58], a hybrid approach combining fuzzy BWM and interval VIKOR was provided for sustainable circular supplier selection. The AHP was coupled with the VIKOR [44] and the fuzzy VIKOR [43] for green suppliers' performance evaluation and selection. The ANP was integrated with the VIKOR [51] and the neutrosophic VIKOR [52] for sustainable supplier selection and evaluation in supply chains. The fuzzy preference programming, a modification of AHP, was integrated with fuzzy VIKOR by Fallahpour et al. [59] to assess suppliers' performance with respect to carbon management criteria. In addition, Zhou and $\mathrm{Xu}$ [54] developed an integrated DEMATEL-ANP-VIKOR model for sustainable supplier selection with heterogeneous information, Phochanikorn and Tanand [60] suggested an integrated DEMATEL-ANP-VIKOR approach for sustainable supplier selection under intuitionistic fuzzy environment, and Kuo et al. [55] proposed a green supplier selection method using the DEMATEL-based ANP and the VIKOR to evaluate green suppliers in an electronics company.

Quan et al. [62] proposed a hybrid MCDM approach for the evaluation of suppliers' environmental performances within the large group environment. Specifically, intervalvalued intuitionistic uncertain linguistic sets were used for assessing candidate green suppliers, an extended linear programming technique for multidimensional analysis of preference (LINMAP) method was adopted to calculate the objective weights of criteria, and an improved multiobjective optimization by ratio analysis plus the full multiplicative form (MULTIMOORA) technique was applied to rank green suppliers. Liu et al. [63] developed a two-stage integrated model for the supplier selection of the green fresh product. In the first stage, the relationships of customer requirements, company strategies, and selection criteria were analyzed by QFD, and subjective criteria weights were computed by fuzzy BWM. In the second stage, the objective criteria weights were determined by the entropy method, and the most suitable suppliers were obtained using the fuzzy MULTIMOORA method. Mohammadi et al. [64] presented a group decision-making method for evaluating and ranking green suppliers, in which the relative preference relation was employed to weight selection criteria and the interval type-2 fuzzy MULTIMOORA method was applied for selecting the best green supplier. Liu et al. [65] developed a large-scale green supplier selection approach based on q-rung interval-valued orthopair fuzzy sets and the MULTIMOORA method, and Liou et al. [66] reported a datadriven green supplier evaluation model using the random forest algorithm, the DEMATEL-based ANP, and the multiobjective optimization on the basis of ratio analysis to the aspiration level (MOORA-AS) method.

3.3. Outranking Methods. Fourteen articles in the data set proposedthe outranking methods for achieving sustainable supplier selection. Kumar et al. [69] evaluated the suppliers' performances based on green practices using the fuzzy ELECTRE (elimination and choice translating reality) approach. $\mathrm{Lu}$ et al. [68] evaluated and selected the right suppliers by the use of an integrated method based on rough set theory and the ELECTRE approach. Shojaie et al. [67] examined the suppliers of a pharmaceutical company by 
using the fuzzy ELECTRE and the entropy method in order to achieve a green health supply chain. Gitinavard et al. [70] investigated the green supplier evaluation problem in manufacturing systems by using the interval-valued hesitant fuzzy ELECTRE and the maximizing deviation method. Tsui and Wen [71] analyzed and prioritized green polarizer suppliers via a hybrid MCDM model, in which the AHP and the entropy method were used to measure the compromised weights of criteria and the ELECTRE III method was adopted to provide the ranking results for executive managers. Guarnieri and Trojan [72] proposed a model which combines AHP with the ELECTRE-TRI to support supplier selection based on social, ethical, and environmental criteria.

Abdullah et al. [74] selected the right suppliers by using the preference ranking organization method for enrichment evaluation (PROMETHEE) under the usual criterion preference functions, and Govindan et al. [75] addressed the green supplier selection problem in the food supply chain by combining revised Simos procedure and PROMETHEE method. Based on the fuzzy AHP and the PROMETHEE methods, Roy et al. [73] established a framework for sustainable supplier selection with heterogeneous information. Wan et al. [76] presented a hesitant fuzzy PROMETHEE method for green supplier selection, in which an entropybased nonlinear programming model was built to determine criteria weights. The hesitant fuzzy QUALIFLEX method was proposed by Liang and Chong [77] for green supplier selection in the Hong Kong-Zhuhai-Macau bridge project. The probability hesitant fuzzy QUALIFLEX model was suggested by Li and Wang [78] for selecting green suppliers in an automobile manufacturing company. In [79], an integrated decision support framework using cloud model theory and the QUALIFLEX method was developed for the evaluation of qualified green suppliers, and a TOPSIS-based optimization model was constructed to derive the criteria weights with unknown or incompletely known weight information. In [80], a green supplier selection approach for heterogeneous information and dependent criteria based on the QUALIFLEX method and the Choquet integral was proposed.

3.4. Pairwise Comparison Methods. Eleven of the reviewed research studies suggested pairwise comparison methods for the selection of optimal green suppliers. The fuzzy AHP [81], the interval type-2 fuzzy AHP [85], the voting AHP [82], and the multiplicative AHP [83] were used for evaluating the performance and selecting the best green supplier in different areas. Xu et al. [84] proposed the use of the sorting method, AHP Sort II, to assess green suppliers in interval type-2 fuzzy environment. The ANP approach was employed in choosing the most suitable sustainable supplier in a white goods manufacturer [86], a bicycle manufacturer [87], an electronics company [88], and multiple manufacturing companies [90]. Büyüközkan and Çifçi [89] developed an approach based on fuzzy ANP within the multiperson decision-making scheme under incomplete preference relations for sustainable supplier selection. Liu et al. [91] reported a model by integrating BWM and alternative queuing method (AQM) within the interval-valued intuitionistic uncertain linguistic setting to evaluate and select sustainable suppliers under interval-valued intuitionistic uncertain linguistic environment.

3.5. Mathematical Programming Methods. The mathematical programming methods have been used by 22 studies for suppliers' green performance evaluation. Dobos and Vörösmarty [93] evaluated and improved the green performance of suppliers using data envelopment analysis (DEA) with incomplete data, and Jafarzadeh Ghoushchi et al. [94] selected sustainable suppliers in the supply chain with a goal programming-DEA model in the presence of imprecise data. Dobos and Vörösmarty [92] developed a DEA-type green supplier selection method, in which the effect of inventory ordering and holding costs on the selected supplier is considered. Wang et al. [97] integrated fuzzy AHP and DEA to identify the optimal suppliers for edible oil production. Kuo and Lin [98] provided an approach using ANP and DEA for evaluating green suppliers, and Kuo et al. [99] built a green supplier selection system by combing the artificial neural network and the ANP into DEA. Kumar et al. [105] proposed a green DEA (GDEA) approach to model the supplier selection problem considering both cost cutting and environmental efficiency. Later, two advanced GDEA modes, the carbon market sensitive-GDEA [103] and the genetic/immune strategy-GDEA [104], were presented for performance evaluation and selection of sustainable suppliers. A systematic DEA approach was introduced in [107] to select suppliers for a sustainable supply chain, and a genetic programming-based DEA method was applied in [106] for green supplier selection under fuzzy environment. In addition, the two-stage DEA [95], the differential evolution-based DEA [96, 101], the fuzzy DEA [100], the interval-valued Pythagorean fuzzy DEA [108], the context-dependent DEA [109], and the ecoefficiency DEA [102] have been established for sustainable supplier evaluation and selection.

Pandey et al. [112] reported a two-phase fuzzy goal programming approach integrating hyperbolic membership function to determine suppliers under the sustainable supply chain environment. Bakeshlou et al. [110] constructed a multiobjective fuzzy linear programming model to solve the green supplier selection problem. In this study, the fuzzy DEMATEL method was used to analyze the interrelations among criteria, and the fuzzy ANP method was utilized to compute the criteria weights with respect to their dependencies. Yeh and Chuang [113] suggested an optimum mathematical planning model for selecting suppliers in green supply chain problems and employed two multiobjective genetic algorithms to find the set of Pareto-optimal solutions. A multiobjective mixed-integer programming model was introduced in [111] to identify optimal suppliers for a green supply chain network considering green factors and stochastic parameters.

3.6. Value and Utility Methods. From the review, it has been found that 30 articles used various value and utility methods for solving the green supplier selection problems. The TODIM (an acronym in Portuguese of interactive and multicriteria decision-making) method has been extended by 
Qin et al. [115] and Sang and Liu [116] for green supplier selection in the context of interval type-2 fuzzy sets. Bai et al. [114] put forward a grey-based group decision support approach composed of the BWM and the TODIM for social green supplier evaluation and selection, and Arshadi Khamseh and Mahmoodi [117] presented the fuzzy TOPSISTODIM hybrid model to choose the best sustainable supplier using fuzzy time function. In [119], the TODIM method was combined with continuous interval-valued linguistic term sets to solve green supplier selection problems. In [118], a green supplier selection approach was suggested based on q-rung orthopair fuzzy sets and the TODIM method, and the weights of criteria were computed by a subjective weighting method and a deviation maximization model.

Phochanikorn and Tan [120] designed an integrated decision-making model based on prospect theory for green supplier selection. It used the fuzzy DEMATEL method to consider the cause and effect relationships of relevant criteria and the fuzzy ANP to assign their weights; the prospect theory was applied to synthesize procurement's psychological and behavioral factors in selecting green suppliers. $\mathrm{Wu}$ et al. [121] provided a sustainable photovoltaic module supplier selection model based on triangular intuitionistic fuzzy numbers and cumulative prospect theory. Further, a method combining AHP and entropy theory is proposed to measure the importance of evaluation criteria. An integrated decision framework based on the third-generation prospect theory was given in [122] for sustainable supplier selection under heterogeneous information environment.

The fuzzy axiomatic design approach was used by Guo et al. [123] to address the green supplier selection problem in apparel manufacturing, by Kannan et al. [124] to select the best green supplier for an engineering plastic material manufacturer, and combined with the fuzzy AHP by Büyüközkan [125] to evaluate green supplier alternatives for a Turkish automotive company. Rabbani et al. [126] provided a method for sustainable supplier selection by using intervalvalued fuzzy sets and possibilistic statistical reference point systems, and Foroozesh et al. [127] presented a method for green supplier performance evaluation with the intervalvalued fuzzy possibilistic statistical model and FMEA. Foroozesh et al. [128] reported interval-valued fuzzy sets and possibilistic statistical approach to select the sustainable supplier for manufacturing services with the lowest risk.

Sinha and Anand [129] presented a framework based on the digraph and matrix method for supplier selection in new product development from sustainability perspective, and KhanMohammadi et al. [209] employed the fuzzy group graph theory and matrix approach for supplier evaluation in sustainable supply chain management. Yazdani et al. [130] considered customer attitudes in the green supplier selection process and applied step-wise weight assessment ratio analysis (SWARA), QFD, and weighted aggregated sum-product assessment (WASPAS) for selecting the optimum green supplier. Zavadskas et al. [131] proposed the use of an interval type-2 fuzZy WASPAS method for multicriteria evaluation of green suppliers, and Mishra et al. [132] suggested a hesitant fuzzy WASPAS method for the assessment of green suppliers based on exponential information measures. A rough complex proportional assessment (COPRAS) model was developed in [133] for sustainable supplier selection in a construction company. An intuitionistic fuzzy COPRAS method based on parametric measures was proposed in [134] to solve the green supplier selection problem. In addition, the researchers have proposed other green supplier selection methods based on the multiple attribute utility theory [135], the range of value [137], the possibility degree [138], the fuzzy comprehensive evaluation [139], the fuzzy performance index [140], the fuzzy preference relationship [141], the piecewise linear value function [142], and the measurement of alternatives and ranking according to compromise solution (MARCOS) method [136].

3.7. Aggregation Operator-Based Methods. Twelve studies have proposed a variety of aggregation operator-based methods for evaluating and selecting suppliers in the sustainable supply chain. Wu et al. [143] selected the optimal green supplier of electric vehicle charging facility based on the Choquet integral operator and interval type-2 fuzzy uncertainty. Shahryari Nia et al. [146] determined the best green supplier for a manufacturing company using interval-valued intuitionistic fuzzy sets and the Choquet integral operator. $\mathrm{Zhu}$ and $\mathrm{Li}$ [145] established an integrated framework combining the consensus reaching process, the prioritized operator, and the Choquet integral for green supplier selection under hesitant fuzzy linguistic environment. Wang and Li [118] proposed a Choquet integral-based model for sustainable supplier selection which considers the interaction among criteria with heterogeneous decision information.

$\mathrm{Xu}$ et al. [147] dealt with the GSES problem by using the interval 2-tuple hybrid averaging (ITHA) operator, the interval 2-tuple ordered weighted averaging-weighted averaging (ITOWAWA) operator, and the interval 2-tuple hybrid geometric operator. Liu et al. [148] addressed the GSES problem with the prioritized average operator under ordered weighted hesitant fuzzy environment. Liu et al. [149] investigated the green supplier selection problem by combining QFD with partitioned Bonferroni mean operator in the context of interval type- 2 fuzzy environment. In addition, the fuzzy weighted average operator [152], the 2-tuple ordered weighted averaging (TOWA) operator [153], the hesitant fuzzy Hamacher power weighted average (HFHPWA) operator [150], the interval-valued intuitionistic fuzzy geometric weighted Heronian means (IVIFGWHM) operator [151], and the single-valued triangular neutrosophic Dombi prioritized normalized Bonferroni mean (SVTNDPNBM) operator [154] have been employed for evaluation and selection of the best supplier in green supply chain management.

3.8. Combined Supplier Selection Methods. It can also be found from the literature review that 14 studies have combined multiple methods to generate green supplier rankings in solving GSES problems. Chen [155] developed a multicriteria assessment model based on the GRA-TOPSIS for sustainable building material supplier selection in intuitionistic fuzzy setting, and Shi et al. [156] put forward an integrated approach using the GRA-TOPSIS for green 
agrifood supplier selection with interval-valued intuitionistic uncertain linguistic information. Yu et al. [165] proposed a hybrid sustainable supplier selection approach integrating teh TOPSIS and the ELECTRE methods, and Mao et al. [166] presented an integrated interval-valued intuitionistic fuzzy sustainable supplier selection approach based on the TOPSIS and the TODIM methods. Sen et al. [157] applied the methods of TOPSIS, MOORA, and GRA for evaluating sustainability performance of suppliers under intuitionistic fuzzy context, and Banaeian et al. [158] used the methods of TOPSIS, VIKOR, and GRA for green supplier evaluation and selection in fuzzy environment. In [167], a hybrid model based on the adaptive neurofuzzy inference system (ANFIS) and the TOPSIS was implemented for sustainable supplier selection. In [168], an integrated method based on the fuzzy inference system (FIS) and the fuzzy TOPSIS was used to evaluate the supplier's sustainability performance.

Yazdani et al. [159] developed an integrated approach consisting of DEMATEL, QFD, COPRAS, and MOORA for selecting the best green supplier, and Tavana et al. [160] provided an integrated method combining ANP, QFD, MOORA, and WASPAS for sloving sustainable supplier selection problems. Sahu et al. [161] explored the application feasibility of the fuzzy multilevel MCDM (FMLMCDM) approach in evaluating green suppliers by comparing with the fuzzy TOPSIS method. Kaur et al. [162] proposed an integer linear programming model toward the appraisement and selection of green suppliers by integrating the ranking results obtained from AHP, TOPSIS, and interpretive ranking process (IRP). Girubha et al. [163] first used the combination of interpretative structural modelling and ANP for computing the weights of criteria considering their interactions and then applied both VIKOR and ELECTRE algorithms to determine the ranking of available sustainable suppliers. An integrated model was developed in [164] to facilitate supplier selection in the sustainable supply chain by combing fuzzy AHP, fuzzy additive ratio assessment (ARAS), and multisegment goal programming (MSGP) techniques.

3.9. Other Supplier Selection Methods. There are nine studies addressing the GSES problems with other methods. Zhang and Cui [169] designed a model combining the Bayesian network with an improved genetic algorithm for selecting suppliers of agricultural means of production. Sarkis and Dhavale [170] put forward a triple bottom line approach using Bayesian framework and Monte Carlo Markov chain simulation toward the evaluation and selection of suppliers for sustainable operations. Orji and Wei [171] developed a modelling approach of integrating the fuzzy logic and the system dynamics to rank and select a sustainable supplier in the manufacturing industry. Amindoust et al. [173] introduced a ranking model based on FIS for the selection of suppliers considering sustainable perspectives, and Amindoust and Saghafinia [172] applied a modular model on the basis of FIS for textile supplier selection in the sustainable supply chain. In [174], a stochastic dual hesitant fuzzy linguistic method was proposed based on the group satisfaction degree framework and the regret theory to rank and select green chain suppliers. In [175], a group consensus decision-making model was developed to help choosing the best green supplier for electronics manufacturing. Ma et al. [176] proposed a three-way group decision-making approach to address the selection of the green supplier by extending the decision-theoretic rough sets into hesitant fuzzy linguistic environment. Chen et al. [177] applied the six sigma quality indices to the evaluation of suppliers based on their process yields and quality levels.

\subsection{Supplier Selection and Order Allocation Methods.} There are still 31 articles in the reviewed literature which not only support the selection of the green supplier but also determine order allocation among the potential suppliers. Yadavalli et al. [182] adopted a modified TOPSIS using Znumbers for selecting green suppliers based on customers' expectations, and developed a biobjective mathematical model for allocating optimal amounts to the best performing suppliers. Duan et al. [198] used an extended AQM with linguistic $Z$-numbers for green supplier selection and established a multiobjective line programming (MOLP) mode to determine the optimal order quantity for the qualified green suppliers. Govindan and Sivakumar [183] adopted fuzzy TOPSIS for the rating and selection of green suppliers and used an MOLP model for order allocation among the sleeted suppliers. Tirkolaee et al. [186] implemented a hybrid approach based on fuzzy ANP, fuzzy DEMATEL, and fuzzy TOPSIS to determine the priority of suppliers considering sustainability aspects and developed a multiobjective mixed-integer linear programming model to determine the lot size and program the order allocation.

Kannan et al. [180] presented an integrated approach of fuzzy AHP, fuzzy TOPSIS, and MOLP for rating and selecting the best green suppliers according to economic and environmental criteria, and then allocated the optimum order quantities among them. Similar integrated methods based on the fuzzy AHP, the fuzzy TOPSIS, and the MOLP are also discussed in $[178,179,181,187,188]$ for green supplier selection and order allocation. Lo et al. [184] established a model that integrates the BWM, the fuzzy TOPSIS, and the fuzzy MOLP for solving problems in green supplier selection and order allocation, and Nourmohamadi Shalke et al. [185] proposed a model by using entropy method, TOPSIS, and multichoice goal programming to evaluate the problem of green supplier selection and order allocation considering quantity discounts.

Banaeian et al. [193] introduced a compound green supplier evaluation and order allocation approach, in which the AHP was used to weight green criteria, the fuzzy GRA was utilized to determine the best suppliers, and the MOLP was constructed to allocate the orders among them optimally. Almasi et al. [189] proposed an AHP-based multiobjective and multiperiod mathematical model for sustainable supplier selection and order allocation under risk and inflation condition, Khoshfetrat et al. [191] suggested an AHP-based fuzzy, multiobjective, multiproduct, and 
multiperiod mathematical model for sustainable supplier selection and order allocation in the automotive industry, and Cheraghalipour and Farsad [194] gave a BWM-based biobjective and multiperiod mathematical model for green supplier selection and quota allocation considering quantity discounts under disruption risks. Shaw et al. [190] developed a sustainable supplier selection and order allocation model using the fuzzy AHP and the fuzzy MOLP for developing a low carbon supply chain. Laosirihongthong et al. [192] obtained the ranking of green suppliers using fuzzy AHP and determined purchasing order allocation among the ranked suppliers using cost minimization subject to multiple criteria of economic, environmental, and social conditions.

Babbar and Amin [195] solved the sustainable supplier selection and order allocation problem by fuzzy QFD and stochastic multiobjective mathematical model. Arabsheybani et al. [196] considered supplier's sustainability and order allocation simultaneously on the basis of the fuzzy MOORA, the FMEA, and the multiobjective mathematical model. Gören [199] investigated the sustainable supplier selection and order allocation problem with lost sales by using a decision framework consisting of fuzzy DEMATEL, Taguchi loss function, and biobjective optimization model. You et al. [197] developed a model for selecting the most suitable sustainable suppliers and determined the optimal order sizes among them by combining double hierarchy hesitant linguistic term sets, decision field theory, and MOLP model.

In [201], the authors developed an inclusive multiobjective mixed-integer linear programming model, which accounts for multiple periods, multiple products, and multimodal transportation, to evaluate suppliers and allocate order quantities. In [202], the authors proposed a multiobjective mixed-integer linear program model for selecting critical suppliers in a global supply chain setting and allocated orders incorporating general business and environmental performance objectives. In [204], a biobjective two-stage mixed possibilistic-stochastic programming model was put forward for the sustainable supplier selection and order allocation problem under operational and disruption risks. In [200], a multiobjective integer linear programming model for multiple sourcing and multiple product designs was used to address the green supplier selection and order allocation problem based on regional information. Moheb-Alizadeh and Handfield [201] considered a multiobjective mixed-integer nonlinear programming model for efficient sustainable supplier selection and order allocation with stochastic demand. In addition, Kim et al. [205] established a mixed-integer programming model for large-scale sustainable supplier selection and order allocation, Tsai and Hung [206] constructed a fuzzy goal programming model for optimal green supplier selection and flow allocation, Yu et al. [165] presented a multiobjective mathematical integer programming to select green suppliers and determine their order allocation, and Jia et al. [207] developed a distributionally robust goal programming model including expected constraints and chance constraints for sustainable supplier selection and order allocation problems.

\section{Findings and Discussions}

In this section, the analyses of the selected reviewed articles regarding green supplier evaluation criteria, criteria weighting methods, and green supplier evaluation methods are described. Also, we conducted a bibliometric analysis on the frequency of the green supplier selection method, citation time, year of publication, journal of publication, country of origin, and application field.

4.1. Green Evaluation Criteria. In traditional supplier selection, only the economic criteria (such as price, quality, and delivery) are taken into account to arrive at a prioritization or final selection of green suppliers. Over the past decade, the topic of green supplier selection has received increasing attention as organizations started to focus on issues of environmental performance in purchasing due to stricter regulations and pressure from various stakeholders. and social criteria have been included by companies to choose a comprehensive sustainable supplier for improving their sustainable supply chain performance. Thus, it is necessary to analyze the green supplier evaluation criteria employed in the reviewed articles. Taken together, a lot of criteria have been mentioned in the selected research studies, but the classification into different groups varies among them. In this study, we divided the identified criteria into economic, environmental, and social dimensions according to the triple bottom line sustainability framework [7, 12]. The most popular evaluation criteria proposed and used in the literature are shown in Table 2.

In summary, 2270 criteria have been identified from the reviewed articles. Grouping the criteria having the same or similar labels, 4930 unique criteria were derived. Among them, $47.45 \%$ economic, $38.41 \%$ environmental, and $14.14 \%$ social criteria are included. From Table 2, we can observe that the most frequently used criteria are quality, resource consumption, price, green design, environmental management system, and greenhouse gas emission. In the economic dimension, quality, price, and cost are the most important criteria in the selected studies. In the environmental dimension, environmental management system, resource consumption, and green design are the most frequently used criteria. Besides, health and safety, interests and rights, and information disclosure are ranked as the top three social criteria in the literature sample. Figure 2 shows the whole intellectual landscapes of co-occurrence green evaluation criteria in the considered field. It can be seen that environmental, green, management, quality, cost, capability, and delivery are the significant green evaluation criteria taking over notable positions.

4.2. Criteria Weighting Methods. An important step of the GSES process is to determine the weight of each green supplier evaluation criterion. In the reviewed literature, multifarious weighting approaches have been proposed for obtaining appropriate criteria weights. Table 3 demonstrates the different types of weighting approaches utilized in the included GSES studies. In general, the currently used 


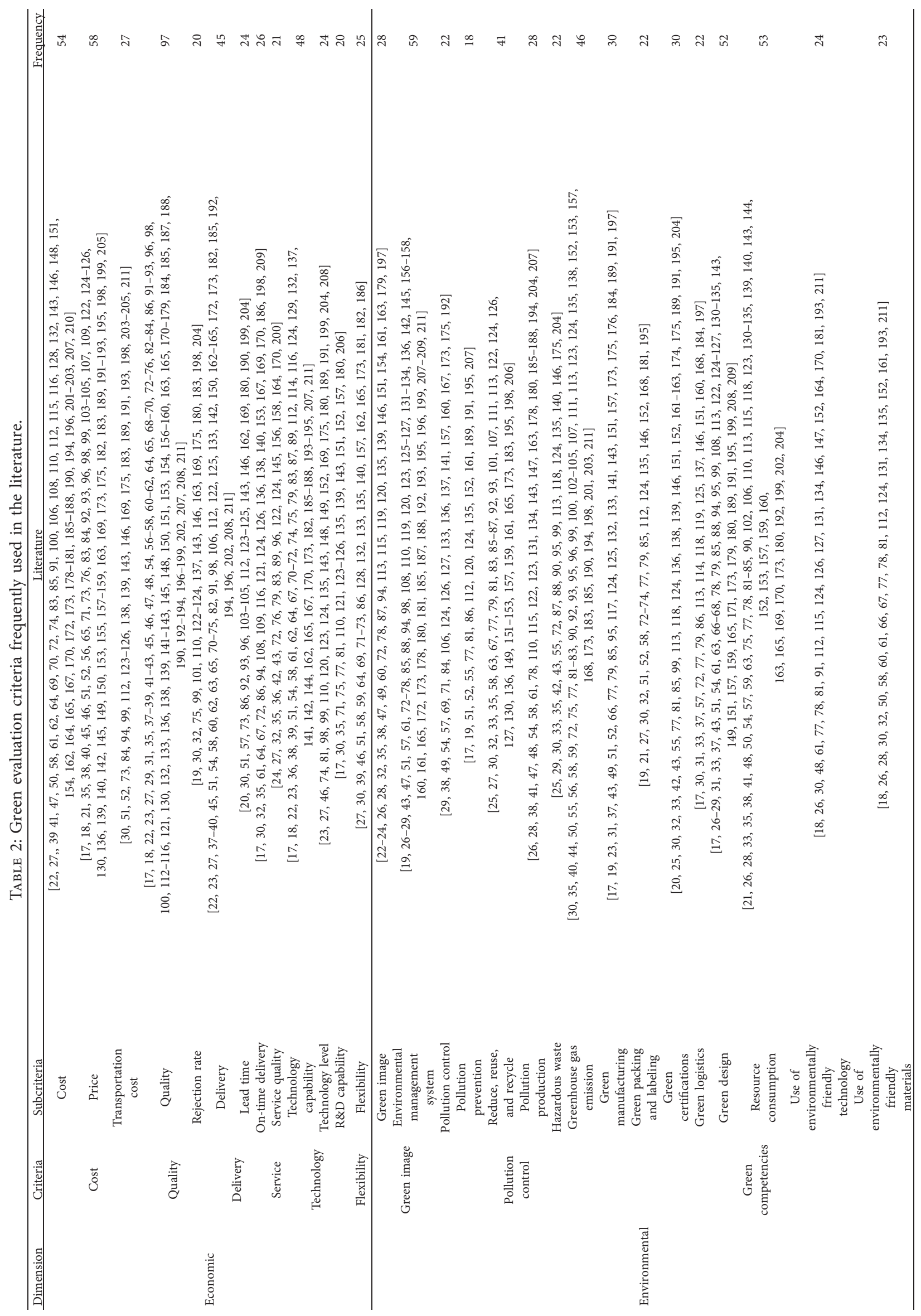




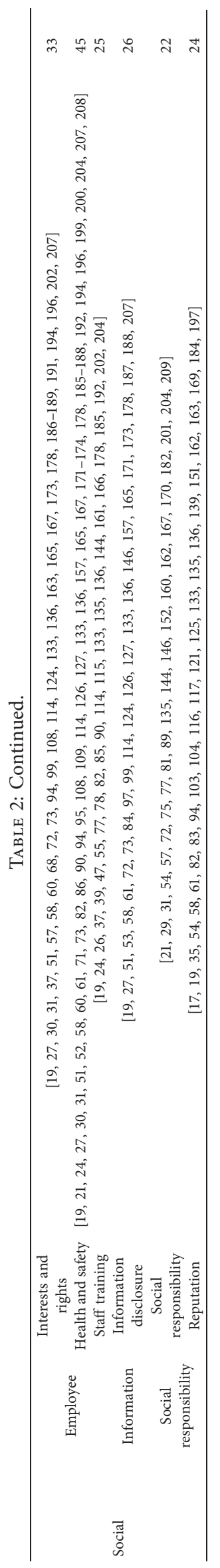




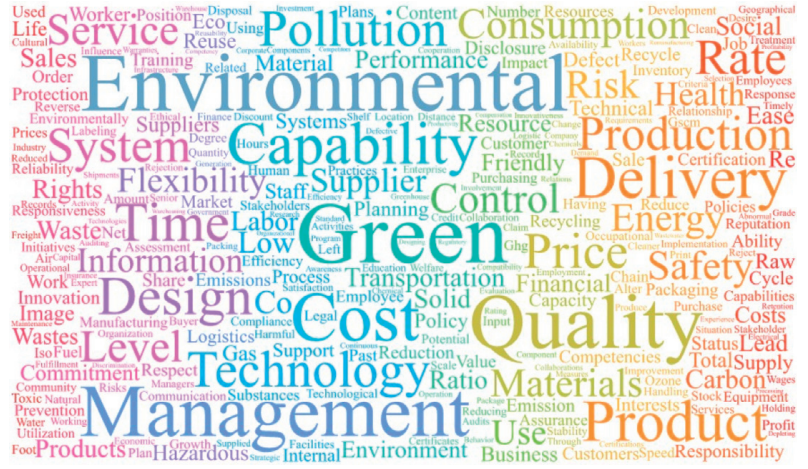

Figure 2: Co-occurrence analysis of the green evaluation criteria.

weighting approaches can be divided into subjective weighting, objective weighting, and combination weighting.

As can be seen in Table 3, the weights of green supplier evaluation criteria are commonly determined according to the judgements of decision makers. The AHP and the ANP methods are also widely acceptable subjective weighting methods and have been used in 23 and 11 papers, respectively. The most frequently used objective weighting method is the DEA method; 15 articles adopted it to evaluate the weights of green supplier evaluation criteria. This was followed by the entropy method, which was employed in 9 researches. To integrate the advantages of both subjective and objective weighting methods, combination weighting methods have been gradually utilized to determine the weights of green supplier evaluation criteria in the literature. For instance, the relative weight values of green supplier evaluation criteria were computed by combining AHP and entropy method in $[32,63,71,121]$. Additionally, there is one study which considered the situation with incomplete criteria weighting information and created a TOPSIS-based optimization model to obtain the optimal weights of evaluation criteria for green supplier selection [79].

4.3. Green Supplier Evaluation Methods. Typically, GSES can be seen as an activity of teamwork and cooperation by a group of decision makers coming from different departments or organizations. During the group GSES process, the evaluation on green suppliers from decision makers is often vague, imprecise, uncertain, and hesitant due to time pressure, lack of data, and human limited information processing capability. To address this issue, a variety of uncertainty theories and methods have been utilized in the reviewed studies. In Table 4, the summarized information from the selected literature regarding green supplier evaluation approaches is shown.

As depicted in Table 4, fuzzy set theory is the widespread used method to manage the fuzziness of green performance evaluation information from decision makers. Particularly, the fuzzy sets based on TFNs are the most preferred approach adopted in the selected papers. Moreover, the interval type-2 fuzzy sets and the intuitionistic fuzzy sets are also frequently used by researchers to deal with the vagueness and uncertainty of performance evaluations in
GSES, which have appeared in 10 and 9 articles, respectively. Considering that decision makers incline to give their opinions with linguistic expressions, some linguistic computing methods have been utilized in the green supplier evaluation process recently, which include the intervalvalued intuitionistic uncertain linguistic set $[62,91,156]$, the hesitant fuzzy linguistic term set $[174,176]$, the cloud model theory [79, 138], and the interval 2-tuple linguistic variable [147].

4.4. Bibliometric Analysis. Table 1 displays the green supplier selection approaches and their frequency of application in the GSES literature. As shown in Table 1, the distance-based methods (31 articles, 16.1\%) have been utilized more than other types of green supplier selection methods; the value and utility methods (30 articles, $15.5 \%)$ is the second most frequently used category for green supplier selection. Besides, the literature review shows that the TOPSIS approach with 21 articles is the most favored technique for the determination of the priority ranking of alternative suppliers in the GSES process, which was followed by the DEA approach with 18 articles. The GRA, the VIKOR, the ELECTRE, and the TODIM are also the green supplier selection methods frequently applied to rank green suppliers; these methods were used in GSES more than five times. As for the green supplier selection and order allocation methods, it can be observed that the integration of TOPSIS and MOLP is the most prevalent way to obtain the best green suppliers and allot the optimal order sizes among them in the selected literature. The frequency of the green supplier selection methods employed in the reviewed 193 articles is shown in Figure 3.

Table 5 lists the top 10 influential research studies according to their average citations and total citations extracted from the Scopus database. As reported in Table 5, the first influential article is [115], which has been cited 75 times per year. This study extended the TODIM methodologies for selecting the optimal green supplier within an interval type- 2 fuzzy context. The second influential article authored by Banaeian et al. [158] was published in 2018 and cited 135 times. This study applied three popular MCDM methods (TOPSIS, VIKOR, and GRA) combined with fuzzy sets for green supplier selection in the agrifood industry. The following influential article is by Hashemi et al. [41] with its average citation 44. This paper developed a GSES model based on the ANP and the GRA methods. In addition, the total number of citations in [81] was the highest (454 citations), indicating that this study has a high impact in the GSES field.

Among the chosen GSES literatures, the number of published articles in different years is shown in Figure 4. It can be observed that the approaches for evaluating and selecting green suppliers have growth significantly in the duration from 2009 to 2020 , especially after 2015 . Note that only five months are considered in this study, and thus the publication quantity is 20 in 2020 . The frequency of published articles on GSES increased to 60 items in 2019 from 3 
TABLE 3: Criteria weighting methods used in the literature.

\begin{tabular}{|c|c|c|c|}
\hline Classification & Weighting methods & References & Frequency \\
\hline \multirow{25}{*}{$\begin{array}{l}\text { Subjective weighting } \\
\text { methods }\end{array}$} & Direct given & {$[20,45,46,56,77,78,153]$} & 7 \\
\hline & & {$[22-26,39,42,43,47,49,68,69,74,112,115,116,123,124,126,127$, } & \\
\hline & Expert judgement & $135,136,140,152,156-158$ & 35 \\
\hline & & $161,166,167,172,173,182,183,209]$ & \\
\hline & $A H P$ & {$[20,50,51,72,81-85,125,164,168,178-181,187-193]$} & 23 \\
\hline & $A N P$ & {$[21,41,52,86-90,97-99]$} & 11 \\
\hline & BWM & {$[17-19,48,58,114,142,184,193,194]$} & 10 \\
\hline & QFD & {$[29,57,149,195]$} & 4 \\
\hline & Fuzzy AHP & {$[73,97,138]$} & 3 \\
\hline & DEMATEL & {$[37,44,162]$} & 3 \\
\hline & $\begin{array}{l}\text { Fuzzy preference } \\
\text { programming }\end{array}$ & {$[30,59]$} & 2 \\
\hline & $\begin{array}{l}\text { programming } \\
\text { Full consistency method }\end{array}$ & [133] & 1 \\
\hline & SWARA & [198] & 1 \\
\hline & PIPERECIA & {$[197]$} & 1 \\
\hline & Simos method & {$[75]$} & 1 \\
\hline & Subjective GRA & [139] & 1 \\
\hline & Subjective TOPSIS & {$[117]$} & 1 \\
\hline & Fuzzy DEMATEL & [199] & 1 \\
\hline & DEMATEL, ANP & {$[36,54,55,60,66,110,186]$} & 7 \\
\hline & $\begin{array}{c}\text { Fuzzy DEMATEL, fuzzy } \\
\text { ANP }\end{array}$ & {$[120]$} & 1 \\
\hline & ISM, ANP & {$[163]$} & 1 \\
\hline & DEMATEL, QFD & [159] & 1 \\
\hline & ANP, QFD & {$[160]$} & 1 \\
\hline & SWARA, QFD & {$[130]$} & 1 \\
\hline & BWM, FGCM & {$[38]$} & 1 \\
\hline \multirow{15}{*}{$\begin{array}{l}\text { Objective weighting } \\
\text { methods }\end{array}$} & $D E A$ & {$[92-96,100-109]$} & 15 \\
\hline & Entropy method & {$[27,28,61,65,67,128,155,165,185]$} & 9 \\
\hline & Choquet integral & {$[80,143-146]$} & 5 \\
\hline & $\begin{array}{l}\text { Maximizing deviation } \\
\text { method }\end{array}$ & {$[35,70]$} & 2 \\
\hline & Ordered weight & {$[141,150]$} & 2 \\
\hline & $\begin{array}{c}\text { Hesitant fuzzy entropy } \\
\text { measure }\end{array}$ & {$[76]$} & 1 \\
\hline & $\begin{array}{l}\text { Divergence measure } \\
\text { method }\end{array}$ & {$[134]$} & 1 \\
\hline & Grey incidence entropy & {$[40]$} & 1 \\
\hline & Objective GRA & {$[122]$} & 1 \\
\hline & $\begin{array}{l}\text { Objective TOPSIS } \\
\text { (incomplete weight) }\end{array}$ & {$[79]$} & 1 \\
\hline & LINMAP & [149] & 1 \\
\hline & Relative preference relation & {$[64]$} & 1 \\
\hline & Preference selection index & {$[137]$} & 1 \\
\hline & Time sequence weight & {$[151]$} & 1 \\
\hline & Delphi method & [208] & 1 \\
\hline \multirow{9}{*}{$\begin{array}{l}\text { Combination } \\
\text { weighting methods }\end{array}$} & AHP and entropy method & {$[32,63,71,121]$} & 4 \\
\hline & $\begin{array}{l}\text { Expert judgement and } \\
\text { entropy method }\end{array}$ & {$[34,131]$} & 2 \\
\hline & $\begin{array}{l}\text { Entropy method and } \\
\text { divergence measure method }\end{array}$ & {$[132]$} & 1 \\
\hline & Expert judgement and & & \\
\hline & maximizing distance & {$[33]$} & 1 \\
\hline & method & & \\
\hline & $\begin{array}{c}\text { Expert judgement and } \\
\text { maximizing deviation } \\
\text { method }\end{array}$ & [118] & 1 \\
\hline & $\begin{array}{c}\text { Expert judgement and } \\
\text { statistical variance method }\end{array}$ & {$[31]$} & 1 \\
\hline & $\begin{array}{l}\text { Direct given and ordered } \\
\text { weight }\end{array}$ & {$[147]$} & 1 \\
\hline
\end{tabular}




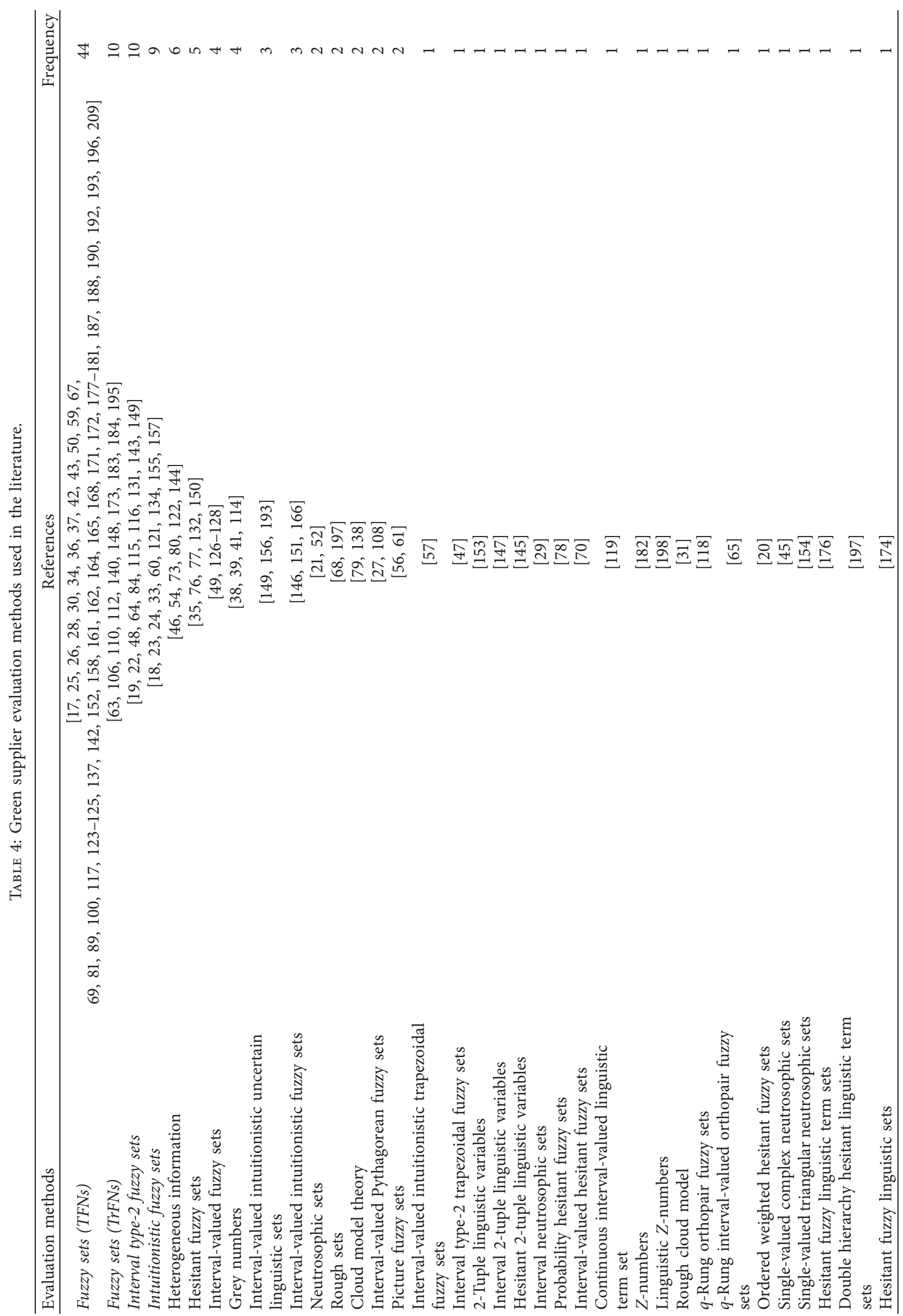




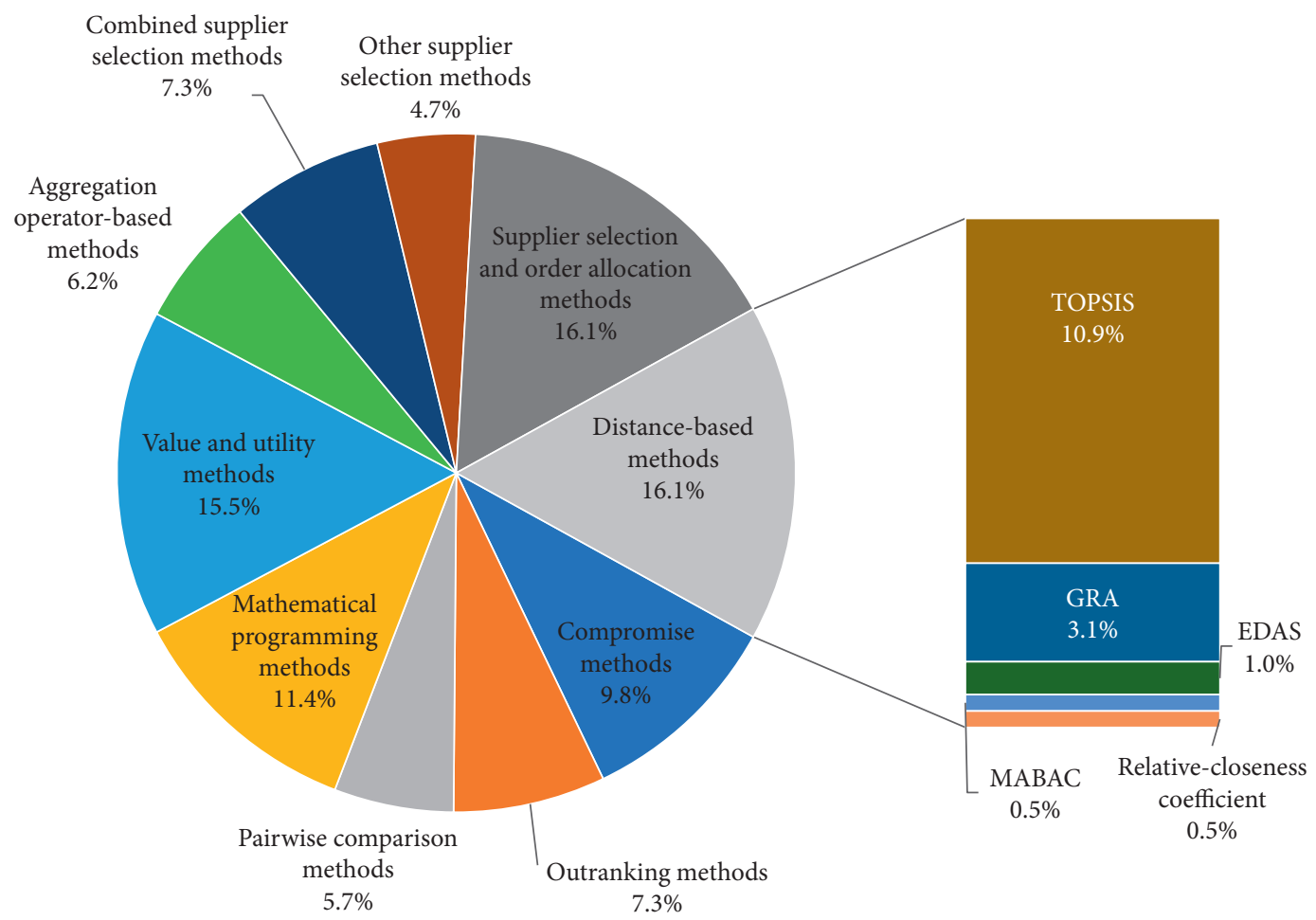

FIgURE 3: Green supplier selection methods in the reviewed literature.

TABLE 5: Top 10 influential papers.

\begin{tabular}{lcc}
\hline Papers & Average citation & Total citation \\
\hline Qin et al. [115] & 75 & 224 \\
Banaeian et al. [158] & 68 & 135 \\
Hashemi et al. [41] & 44 & 222 \\
Lee et al. [81] & 41 & 454 \\
Yazdani et al. [159] & 41 & 123 \\
Kuo et al. [99] & 34 & 341 \\
Shen et al. [26] & 34 & 235 \\
Govindan et al. [75] & 20 & 61 \\
Tsai and Hung [206] & 15 & 167 \\
Tseng [43] & 13 & 113 \\
\hline
\end{tabular}

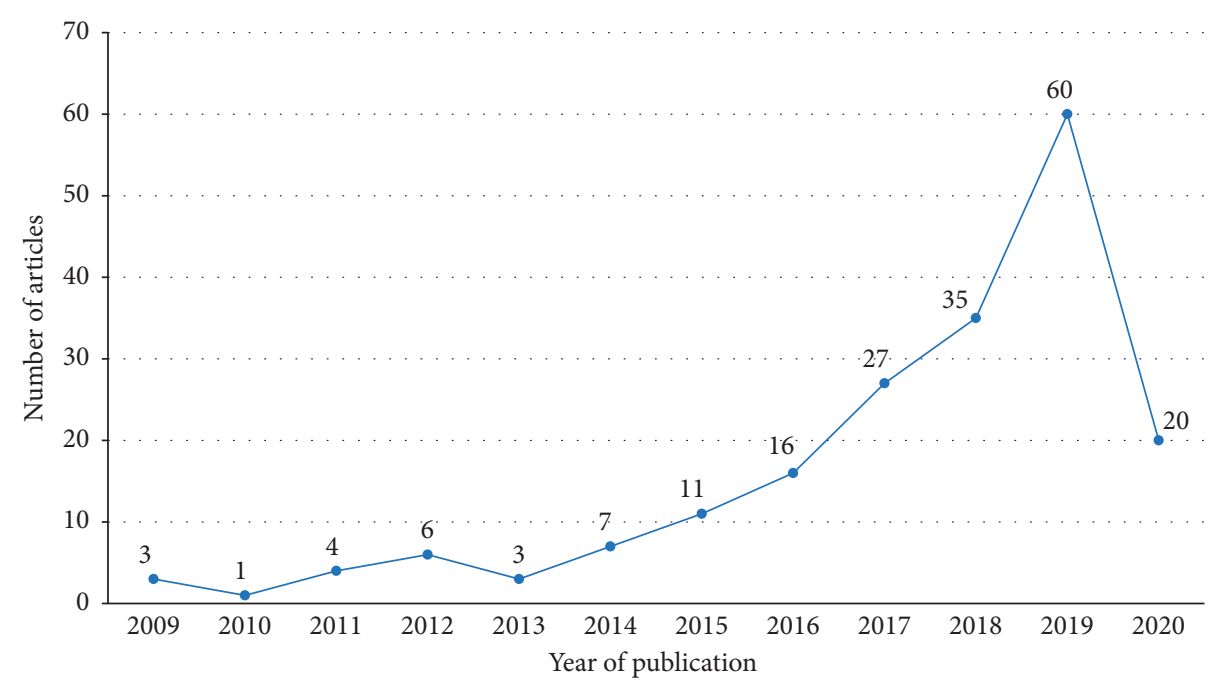

FIGURE 4: Distribution of articles by the publication year. 


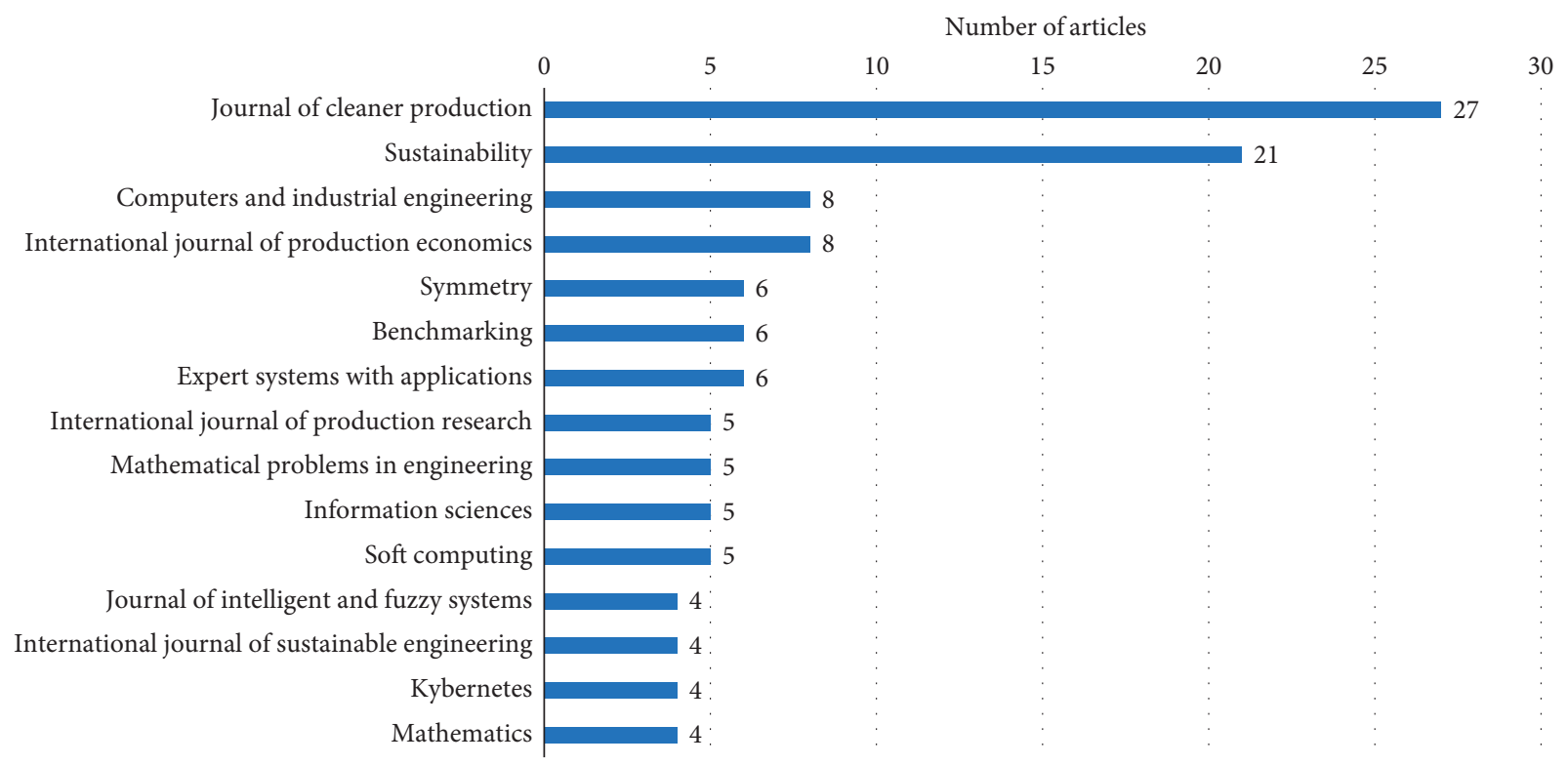

FIgURE 5: Distribution of articles by the publication journal.

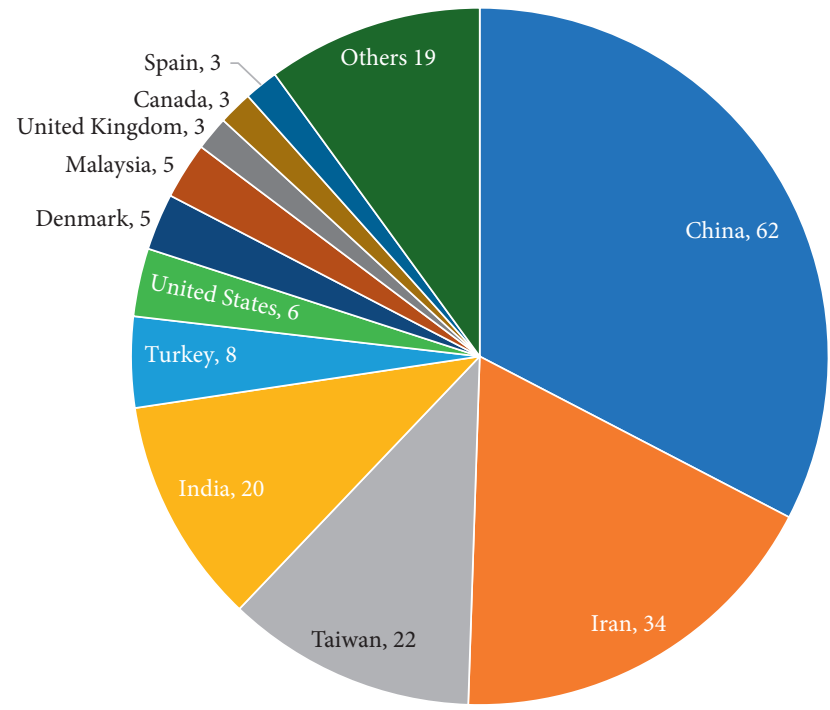

FIgURE 6: Distribution of articles with respect to the country.

items in $2009 ; 63.2 \%$ of the articles in the area are published in the three years (2017-2019). This can be attributed to the fact that sustainability has become a more and more significant portion in enterprise operation management due to growth of customer environmental consciousness, stringent governmental regulations, and stress from inside and outside stakeholders. In addition, some literature reviews of green supply chain management have been published in 2015 focusing on bibliometric and network analysis [4], modelling techniques [6, 12], and theoretical framework development [6]. Nowadays, it is a challenging task for academicians and practitioners to evaluate and select the most appropriate green suppliers in different stages of product life cycle. Thus, it is anticipated that the number of research studies on the GSES will increase quickly in the next years.
Figure 5 displays the journals with more than four papers on the GSES. It can be seen that the Journal of Cleaner Production is the leading journal in GSES problems with 27 published articles, followed by Sustainability with 21 articles. Besides, Computers and Industrial Engineering and International Journal of Production Economics have published 8 articles in this field. Figure 6 depicts the number of the reviewed publications on the basis of the country of origin. As can be seen from the figure, more than $71.5 \%$ of the considered publications (138 articles) are derived from four countries and regions (China, Iran, Taiwan, and India), and China with 62 articles is ranked as the first based on the number of articles followed by Iran with 34 articles. Figure 7 shows the applied field distribution of the selected articles. The result demonstrates that the proposed GSES methods have been utilized in a variety of fields, and the top four application domains are automobile industry (53 articles), electronics industry (25 articles), manufacturing industry (20 articles), and food industry (19 articles), respectively. Furthermore, the GSES methods have been commonly used in construction, energy and chemical, and home appliance industries.

\section{Future Research Recommendations}

This review study demonstrates that GSES has attracted a lot of attention from scholars and a variety of GSES models have been proposed mainly from the aspects of performance assessment, evaluation criteria weighting, and alternative suppliers ranking. Based on the results of this review, many opportunities can be identified for future research, and the following ones are promising directions:

(1) Considering the performance information of alternative suppliers is usually vague, uncertain, or even incomplete, so it is suggested to use the latest uncertainty theories to effectively manipulate uncertainties from human judgements, manage 


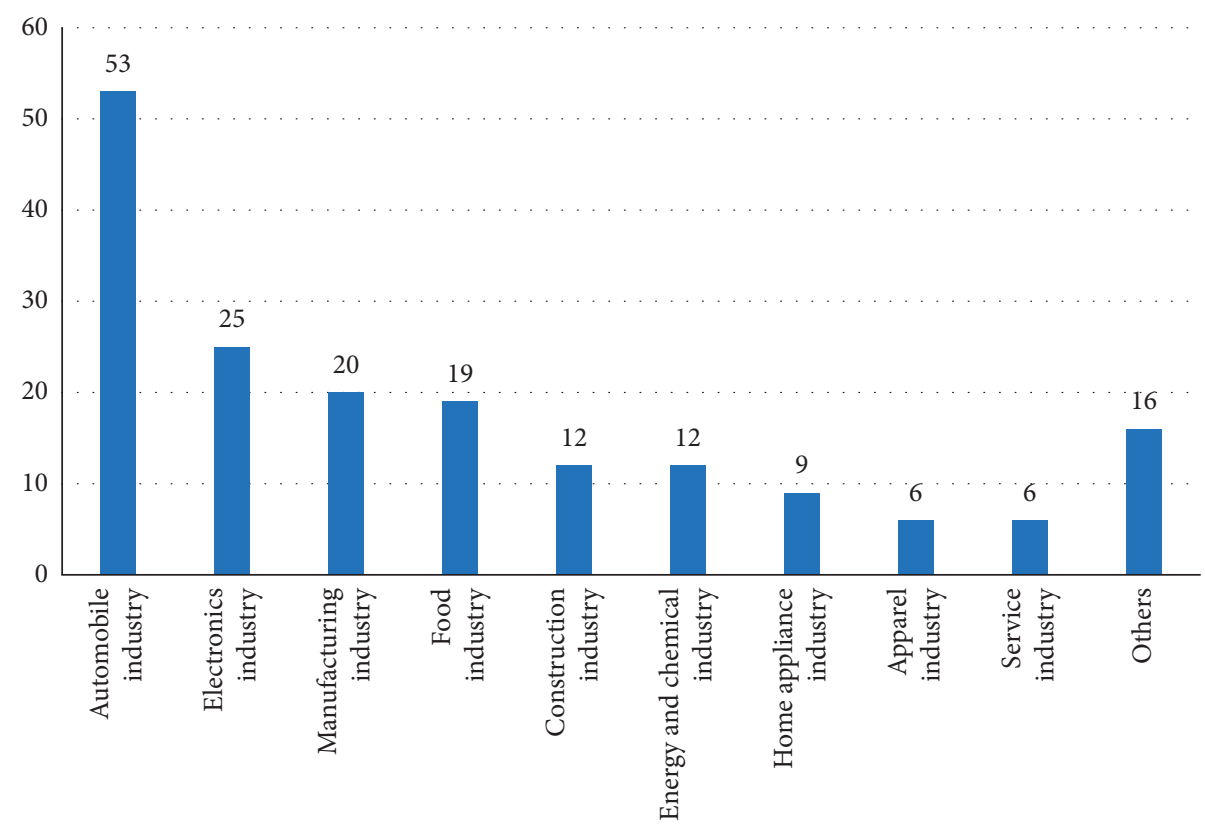

Figure 7: Distribution of articles by the application area.

incomplete performance evaluations and heterogeneous evaluation data, and bring an organized method to characterize decision makers' experience and knowledge for GSES.

(2) Decision makers in the GSES may have different experience, backgrounds, and interests, and thus conflict opinions are unavoidable in the green supplier evaluation process. Thus, as another direction for future studies, consensus methods are suggested to be proposed to solve conflict judgements of decision makers, which will improve group consistency and lead to efficiency improvement in the GSES process.

(3) A variety of weighting methods have been adopted to specify the weights of evaluation criteria in the GSES studies. In the future, it is suggested to explore new subjective weighting, objective weighting, and combination weighting methods. Besides, in some situations, the criteria weight information may be incomplete. Therefore, incomplete weighting approaches should be proposed for obtaining the weights of criteria in the future. In addition, in the reviewed articles, the criteria weights are constant for all alternative green suppliers. It is suggested for the future study to assign different sets of criteria weights for different alternatives in the GSES.

(4) The literature review shows that some scholars started to focus on the determination of decision makers' weights $[16,20,21,51,55]$. As a result, the techniques to acquire the weights of decision makers are suggested to be studies in the future research. Particularly, it would be very meaningful to dynamically assigning decision makers' weights based on their given evaluation information for alternative suppliers.
(5) It is found that MCDM methods are the most popular tools for determining the priority ranking of green suppliers. Future research can be targeted towards applying other MCDM methods such as MACBETH, UTASTAR, and THESEUS to support decision-making in the GSES. Also, to combine the superiorities of different MCDM approaches, future research is suggested to propose GSES models by using multiple or integrated MCDM methods.

(6) In recent years, data have started to be generated on a large volume in the GSCM field. It has been expected that the amount of data will continue to increase largely due to the complexity of GSES problems. Therefore, with regard to the presentation of a large number of criteria and alternatives, we suggest to propose modify methods to handle such data in the GSES.

(7) Another possible direction for future work would be to employ techniques such as intelligent algorithms and system dynamics to efficiently solve GSES problems. For instance, deep learning algorithms can be employed to learn criteria weights from the evaluation data of decision makers on every green supplier. Also, MCDM methods can be empowered by neural networks to consider fluctuations in the ranking of alternative suppliers in the way changes occur in the human brain.

\section{Conclusions}

With the increasing awareness on environmental issues and growing pressure from internal and external stakeholders, companies are adopting GSCM in their supply chain practices to achieve positive outcomes on environmental, social, and economic aspects. In response, a lot of models have been developed for evaluating and selecting green 
suppliers in the literature. In this study, we conducted a comprehensive review of the publications that concern quantitative models for supporting green supplier selection. A total of 193 articles published in peer-reviewed journals between 2009 and 2020 were identified as relevant to this review from the Scopus database. According to the GSES methods being proposed, the chosen articles were classified into ten categories, i.e., distance-based methods, compromise methods, outranking methods, pairwise comparison methods, mathematical programming methods, aggregation operator-based methods, value and utility methods, combined methods, other green supplier selection methods, and SSOA methods. Further, we find that the TOPSIS and the DEA are the two most popular methods applied to determine the ranking orders of candidate sustainable suppliers. Second, it is discovered that the most frequently used green evaluation criteria are quality, resource consumption, price, green design, environmental management system, and greenhouse gas emission. The subjective weighting, objective weighting, and combination weighting methods are all adopted in prior researches to calculate the important weights of green evaluation criteria. Moreover, the criteria weights are mostly obtained on the basis of decision makers' expert judgements. The analysis of green supplier evaluation methods showed that fuzzy set theory is the most preferred approach employed to handle fuzzy and imprecise performance evaluation information. This review study provides academics and practitioners with a guideline and insight into further proposing and applying the GSES approaches to help firms improve environmental sustainability and gain higher competitive performance.

\section{Conflicts of Interest}

The authors declare no conflicts of interest.

\section{Acknowledgments}

This work was supported by the National Natural Science Foundation of China (nos. 71701153 and 71671125) and the Open Research Fund Project of Key Laboratory of Quality Infrastructure Efficacy Research (no. KF20180303).

\section{References}

[1] A. Bastas and K. Liyanage, "Sustainable supply chain quality management: a systematic review," Journal of Cleaner Production, vol. 181, pp. 726-744, 2018.

[2] E. Koberg and A. Longoni, "A systematic review of sustainable supply chain management in global supply chains," Journal of Cleaner Production, vol. 207, pp. 1084-1098, 2019.

[3] D. R. Maditati, Z. H. Munim, H.-J. Schramm, and S. Kummer, "A review of green supply chain management: from bibliometric analysis to a conceptual framework and future research directions," Resources, Conservation and Recycling, vol. 139, pp. 150-162, 2018.

[4] B. Fahimnia, J. Sarkis, and H. Davarzani, "Green supply chain management: a review and bibliometric analysis," International Journal of Production Economics, vol. 162, pp. 101-114, 2015.
[5] N. Jain and A. R. Singh, "Sustainable supplier selection criteria classification for Indian iron and steel industry: a fuzzy modified Kano model approach," International Journal of Sustainable Engineering, vol. 13, no. 1, pp. 17-32, 2020.

[6] R. K. Malviya and R. Kant, "Green supply chain management (GSCM): a structured literature review and research implications," Benchmarking: An International Journal, vol. 22, no. 7, pp. 1360-1394, 2015.

[7] K. Zimmer, M. Fröhling, and F. Schultmann, "Sustainable supplier management-a review of models supporting sustainable supplier selection, monitoring and development," International Journal of Production Research, vol. 54, no. 5, pp. 1412-1442, 2016.

[8] A. Wetzstein, E. Hartmann, W. C. Benton, and N.-O. Hohenstein, "A systematic assessment of supplier selection literature-state-of-the-art and future scope," International Journal of Production Economics, vol. 182, pp. 304-323, 2016.

[9] S. Badi and N. Murtagh, "Green supply chain management in construction: a systematic literature review and future research agenda," Journal of Cleaner Production, vol. 223, pp. 312-322, 2019.

[10] C. Fang and J. Zhang, "Performance of green supply chain management: a systematic review and meta analysis," Journal of Cleaner Production, vol. 183, pp. 1064-1081, 2018.

[11] A. Mardani, D. Kannan, R. E. Hooker, S. Ozkul, M. Alrasheedi, and E. B. Tirkolaee, "Evaluation of green and sustainable supply chain management using structural equation modelling: a systematic review of the state of the art literature and recommendations for future research," Journal of Cleaner Production, vol. 249, Article ID 119383, 2020.

[12] M. Igarashi, L. de Boer, and A. M. Fet, "What is required for greener supplier selection? A literature review and conceptual model development," Journal of Purchasing and Supply Management, vol. 19, no. 4, pp. 247-263, 2013.

[13] A. Konys, "Green supplier selection criteria: from a literature review to a comprehensive knowledge base," Sustainability, vol. 11, no. 15, p. 4208, 2019.

[14] A. Banasik, J. M. Bloemhof-Ruwaard, A. Kanellopoulos, G. D. H. Claassen, and J. G. A. J. van der Vorst, "Multicriteria decision making approaches for green supply chains: a review," Flexible Services and Manufacturing Journal, vol. 30, no. 3, pp. 366-396, 2016.

[15] K. Govindan, S. Rajendran, J. Sarkis, and P. Murugesan, "Multi criteria decision making approaches for green supplier evaluation and selection: a literature review," Journal of Cleaner Production, vol. 98, pp. 66-83, 2015.

[16] D. Moher, A. Liberati, J. Tetzlaff, and D. G. Altman, "Preferred reporting items for systematic reviews and metaanalyses: the PRISMA statement," Annals of Internal Medicine, vol. 151, no. 4, pp. 264-269, 2009.

[17] H. Gupta and M. K. Barua, "Supplier selection among SMEs on the basis of their green innovation ability using BWM and fuzzy TOPSIS," Journal of Cleaner Production, vol. 152, pp. 242-258, 2017.

[18] Z. P. Tian, H. Y. Zhang, J. Q. Wang, and T. L. Wang, "Green supplier selection using improved TOPSIS and best-worst method under intuitionistic fuzzy environment," Informatica, vol. 29, no. 4, pp. 773-780, 2019.

[19] M. Yucesan, S. Mete, F. Serin, E. Celik, and M. Gul, “An integrated best-worst and interval type-2 fuzzy TOPSIS methodology for green supplier selection," Mathematics, vol. 7, no. 2, p. 182, 2019. 
[20] H. M. Wang Chen, S. Y. Chou, Q. D. Luu, and T. H. K. Yu, "A fuzzy MCDM approach for green supplier selection from the economic and environmental aspects," Mathematical Problems in Engineering, vol. 2016, Article ID 8097386, 10 pages, 2016.

[21] M. Abdel-Basset, M. Mohamed, and F. Smarandache, "A hybrid neutrosophic group ANP-TOPSIS framework for supplier selection problems," Symmetry, vol. 10, no. 6, p. 226, 2018.

[22] S. Mousakhani, S. Nazari-Shirkouhi, and A. Bozorgi-Amiri, "A novel interval type-2 fuzzy evaluation model based group decision analysis for green supplier selection problems: a case study of battery industry," Journal of Cleaner Production, vol. 168, pp. 205-218, 2017.

[23] B. D. Rouyendegh, A. Yildizbasi, and P. Üstünyer, "Intuitionistic fuzzy TOPSIS method for green supplier selection problem," Soft Computing, vol. 24, no. 3, pp. 2215-2228, 2020.

[24] A. Memari, A. Dargi, M. R. Akbari Jokar, R. Ahmad, and A. R. Abdul Rahim, "Sustainable supplier selection: a multicriteria intuitionistic fuzzy TOPSIS method," Journal of Manufacturing Systems, vol. 50, pp. 9-24, 2019.

[25] D. Kannan, A. B. L. d. S. Jabbour, and C. J. C. Jabbour, "Selecting green suppliers based on GSCM practices: using fuzzy TOPSIS applied to a Brazilian electronics company," European Journal of Operational Research, vol. 233, no. 2, pp. 432-447, 2014.

[26] L. Shen, L. Olfat, K. Govindan, R. Khodaverdi, and A. Diabat, "A fuzzy multi criteria approach for evaluating green supplier's performance in green supply chain with linguistic preferences," Resources, Conservation and Recycling, vol. 74, pp. 170-179, 2013.

[27] C. Yu, Y. Shao, K. Wang, and L. Zhang, "A group decision making sustainable supplier selection approach using extended TOPSIS under interval-valued Pythagorean fuzzy environment," Expert Systems with Applications, vol. 121, pp. 1-17, 2019.

[28] B. M. dos Santos, L. P. Godoy, and L. M. S. Campos, "Performance evaluation of green suppliers using entropyTOPSIS-F," Journal of Cleaner Production, vol. 207, pp. 498-509, 2019.

[29] L. Van, V. Yu, L. Dat, C. Dung, S.-Y. Chou, and N. Loc, "New integrated quality function deployment approach based on interval neutrosophic set for green supplier evaluation and selection," Sustainability, vol. 10, no. 3, p. 838, 2018.

[30] A. Fallahpour, E. Udoncy Olugu, S. Nurmaya Musa, K. Yew Wong, and S. Noori, "A decision support model for sustainable supplier selection in sustainable supply chain management," Computers \& Industrial Engineering, vol. 105, pp. 391-410, 2017.

[31] J. Li, H. Fang, and W. Song, "Sustainable supplier selection based on SSCM practices: a rough cloud TOPSIS approach," Journal of Cleaner Production, vol. 222, pp. 606-621, 2019.

[32] J. Freeman and T. Chen, "Green supplier selection using an AHP-entropy-TOPSIS framework," Supply Chain Management: An International Journal, vol. 20, no. 3, pp. 327-340, 2015.

[33] Q. Cao, J. Wu, and C. Liang, “An intuitionsitic fuzzy judgement matrix and TOPSIS integrated multi-criteria decision making method for green supplier selection," Journal of Intelligent \& Fuzzy Systems, vol. 28, no. 1, pp. 117-126, 2015.
[34] H. Zhao and S. Guo, "Selecting green supplier of thermal power equipment by using a hybrid MCDM method for sustainability," Sustainability, vol. 6, no. 1, pp. 217-235, 2014.

[35] Q. Hou and L. Xie, "Research on supplier evaluation in a green supply chain," Discrete Dynamics in Nature and Society, vol. 2019, Article ID 2601301, 14 pages, 2019.

[36] G. Büyüközkan and G. Çifçi, "A novel hybrid MCDM approach based on fuzzy DEMATEL, fuzzy ANP and fuzzy TOPSIS to evaluate green suppliers," Expert Systems with Applications, vol. 39, no. 3, pp. 3000-3011, 2012.

[37] Z. Chen, X. Ming, T. Zhou, and Y. Chang, "Sustainable supplier selection for smart supply chain considering internal and external uncertainty: an integrated rough-fuzzy approach," Applied Soft Computing, vol. 87, 2020.

[38] S. A. S. Haeri and J. Rezaei, "A grey-based green supplier selection model for uncertain environments," Journal of Cleaner Production, vol. 221, pp. 768-784, 2019.

[39] A. Malek, S. Ebrahimnejad, and R. Tavakkoli-Moghaddam, "An improved hybrid grey relational analysis approach for green resilient supply chain network assessment," Sustainability, vol. 9, no. 8, p. 1433, 2017.

[40] J. Quan, B. Zeng, and D. Liu, "Green supplier selection for process industries using weighted grey incidence decision model," Complexity, vol. 2018, Article ID 4631670, 12 pages, 2018.

[41] S. H. Hashemi, A. Karimi, and M. Tavana, "An integrated green supplier selection approach with analytic network process and improved grey relational analysis," International Journal of Production Economics, vol. 159, pp. 178-191, 2015.

[42] M.-L. Tseng and A. S. F. Chiu, "Evaluating firm's green supply chain management in linguistic preferences," Journal of Cleaner Production, vol. 40, pp. 22-31, 2013.

[43] M.-L. Tseng, "Green supply chain management with linguistic preferences and incomplete information," Applied Soft Computing, vol. 11, no. 8, pp. 4894-4903, 2011.

[44] M. Yazdani, P. Chatterjee, D. Pamucar, and M. D. Abad, "A risk-based integrated decision-making model for green supplier selection: a case study of a construction company in Spain," Kybernetes, vol. 49, no. 4, pp. 1229-1252, 2019.

[45] D. Xu, X. Cui, and H. Xian, "An extended EDAS method with a single-valued complex neutrosophic set and its application in green supplier selection," Mathematics, vol. 8, no. 2, p. 282, 2020.

[46] X. G. Xu, H. Shi, L. J. Zhang, and H. C. Liu, "Green supplier evaluation and selection with an extended MABAC method under the heterogeneous information environment," Sustainability, vol. 11, no. 23, p. 6616, 2019.

[47] S. M. Mousavi, N. Foroozesh, E. K. Zavadskas, and J. Antucheviciene, "A new soft computing approach for green supplier selection problem with interval type-2 trapezoidal fuzzy statistical group decision and avoidance of information loss," Soft Computing, 2020.

[48] Q. Wu, L. Zhou, Y. Chen, and H. Chen, "An integrated approach to green supplier selection based on the interval type-2 fuzzy best-worst and extended VIKOR methods," Information Sciences, vol. 502, pp. 394-417, 2019.

[49] S. Datta, C. Samantra, S. S. Mahapatra, S. Banerjee, and A. Bandyopadhyay, "Green supplier evaluation and selection using VIKOR method embedded in fuzzy expert system with interval-valued fuzzy numbers," International Journal of Procurement Management, vol. 5, no. 5, pp. 647-678, 2012.

[50] A. Awasthi, K. Govindan, and S. Gold, "Multi-tier sustainable global supplier selection using a fuzzy AHP-VIKOR 
based approach," International Journal of Production Economics, vol. 195, pp. 106-117, 2018.

[51] S. Luthra, K. Govindan, D. Kannan, S. K. Mangla, and C. P. Garg, "An integrated framework for sustainable supplier selection and evaluation in supply chains," Journal of Cleaner Production, vol. 140, pp. 1686-1698, 2017.

[52] M. Abdel-Baset, V. Chang, A. Gamal, and F. Smarandache, "An integrated neutrosophic ANP and VIKOR method for achieving sustainable supplier selection: a case study in importing field," Computers in Industry, vol. 106, pp. 94-110, 2019.

[53] C. W. Hsu, R. J. Kuo, and C. Y. Chiou, "A multi-criteria decision-making approach for evaluating carbon performance of suppliers in the electronics industry," International Journal of Environmental Science and Technology, vol. 11, no. 3, pp. 775-784, 2014.

[54] X. Zhou and Z. Xu, "An integrated sustainable supplier selection approach based on hybrid information aggregation," Sustainability, vol. 10, no. 7, p. 2543, 2018.

[55] T. Kuo, C.-W. Hsu, and J.-Y. Li, "Developing a green supplier selection model by using the DANP with VIKOR," Sustainability, vol. 7, no. 2, pp. 1661-1689, 2015.

[56] P. Meksavang, H. Shi, S.-M. Lin, and H.-C. Liu, "An extended picture fuzzy VIKOR approach for sustainable supplier management and its application in the beef industry," Symmetry, vol. 11, no. 4, p. 468, 2019.

[57] A. Liu, Y. Xiao, H. Lu, S.-B. Tsai, and W. Song, "A fuzzy three-stage multi-attribute decision-making approach based on customer needs for sustainable supplier selection," Journal of Cleaner Production, vol. 239, p. 118043, 2019.

[58] D. Kannan, H. Mina, S. Nosrati-Abarghooee, and G. Khosrojerdi, "Sustainable circular supplier selection: a novel hybrid approach," Science of the Total Environment, vol. 722, Article ID 137936, 2020.

[59] A. Fallahpour, K. Y. Wong, S. Rajoo, and A. Mardani, "An integrated fuzzy carbon management-based model for suppliers' performance evaluation and selection in green supply chain management," International Journal of Fuzzy Systems, vol. 22, no. 2, pp. 712-723, 2020.

[60] P. Phochanikorn and C. Tan, "A new extension to a multicriteria decision-making model for sustainable supplier selection under an intuitionistic fuzzy environment," Sustainability, vol. 11, no. 19, p. 5413, 2019.

[61] J.-j. Peng, C. Tian, W.-y. Zhang, S. Zhang, and J.-q. Wang, "An integrated multi-criteria decision-making framework for sustainable supplier selection under picture fuzzy environment," Technological and Economic Development of Economy, vol. 26, no. 3, pp. 573-598, 2020.

[62] M.-Y. Quan, Z.-L. Wang, H.-C. Liu, and H. Shi, "A hybrid MCDM approach for large group green supplier selection with uncertain linguistic information," IEEE Access, vol. 6, pp. 50372-50383, 2018.

[63] A. Liu, Y. Xiao, X. Ji et al., "A novel two-stage integrated model for supplier selection of green fresh product," Sustainability, vol. 10, no. 7, p. 2371, 2018.

[64] H. Mohammadi, F. V. Farahani, M. Noroozi, and A. Lashgari, "Green supplier selection by developing a new group decision-making method under type 2 fuzzy uncertainty," International Journal of Advanced Manufacturing Technology, vol. 93, no. 1-4, pp. 1443-1462, 2017.

[65] L. Liu, W. Cao, B. Shi, and M. Tang, "Large-scale green supplier selection approach under a q-rung interval-valued orthopair fuzzy environment," Processes, vol. 7, no. 9, p. 573, 2019.
[66] J. J. H. Liou, Y.-C. Chuang, E. K. Zavadskas, and G.-H. Tzeng, "Data-driven hybrid multiple attribute decision-making model for green supplier evaluation and performance improvement," Journal of Cleaner Production, vol. 241, Article ID 118321, 2019.

[67] A. A. Shojaie, S. Babaie, E. Sayah, and D. Mohammaditabar, "Analysis and prioritization of green health suppliers using fuzzy ELECTRE method with a case study," Global Journal of Flexible Systems Management, vol. 19, no. 1, pp. 39-52, 2018.

[68] H. Lu, S. Jiang, W. Song, and X. Ming, "A rough multicriteria decision-making approach for sustainable supplier selection under vague environment," Sustainability, vol. 10, no. 8, p. 2622, 2018.

[69] P. Kumar, R. K. Singh, and A. Vaish, "Suppliers' green performance evaluation using fuzzy extended ELECTRE approach," Clean Technologies and Environmental Policy, vol. 19, no. 3, pp. 809-821, 2017.

[70] H. Gitinavard, H. Ghaderi, and M. S. Pishvaee, "Green supplier evaluation in manufacturing systems: a novel interval-valued hesitant fuzzy group outranking approach," Soft Computing, vol. 22, no. 19, pp. 6441-6460, 2018.

[71] C. W. Tsui and U. P. Wen, "A hybrid multiple criteria group decision-making approach for green supplier selection in the TFT-LCD industry," Mathematical Problems in Engineering, vol. 2014, Article ID 709872, 13 pages, 2014.

[72] P. Guarnieri and F. Trojan, "Decision making on supplier selection based on social, ethical, and environmental criteria: a study in the textile industry," Resources, Conservation and Recycling, vol. 141, pp. 347-361, 2019.

[73] S. A. Roy, S. M. Ali, G. Kabir et al., "A framework for sustainable supplier selection with transportation criteria," International Journal of Sustainable Engineering, vol. 13, no. 2, pp. 77-92, 2019.

[74] L. Abdullah, W. Chan, and A. Afshari, "Application of PROMETHEE method for green supplier selection: a comparative result based on preference functions," Journal of Industrial Engineering International, vol. 15, no. 2, pp. 271-285, 2019.

[75] K. Govindan, M. Kadziński, and R. Sivakumar, "Application of a novel PROMETHEE-based method for construction of a group compromise ranking to prioritization of green suppliers in food supply chain," Omega, vol. 71, pp. 129-145, 2017.

[76] S.-p. Wan, W.-c. Zou, L.-g. Zhong, and J.-y. Dong, "Some new information measures for hesitant fuzzy PROMETHEE method and application to green supplier selection," Soft Computing, vol. 24, no. 12, pp. 9179-9203, 2019.

[77] R. Liang and H.-Y. Chong, "A hybrid group decision model for green supplier selection: a case study of megaprojects," Engineering, Construction and Architectural Management, vol. 26, no. 8, pp. 1712-1734, 2019.

[78] J. Li and J.-q. Wang, "An extended QUALIFLEX method under probability hesitant fuzzy environment for selecting green suppliers," International Journal of Fuzzy Systems, vol. 19, no. 6, pp. 1866-1879, 2017.

[79] K.-Q. Wang, H.-C. Liu, L. Liu, and J. Huang, "Green supplier evaluation and selection using cloud model theory and the QUALIFLEX method," Sustainability, vol. 9, no. 5, p. 688, 2017.

[80] Y. Liang, J. Qin, L. Martínez, and J. Liu, “A heterogeneous QUALIFLEX method with criteria interaction for multicriteria group decision making," Information Sciences, vol. 512, pp. 1481-1502, 2020. 
[81] A. H. I. Lee, H.-Y. Kang, C.-F. Hsu, and H.-C. Hung, "A green supplier selection model for high-tech industry," Expert Systems with Applications, vol. 36, no. 4, pp. 79177927, 2009.

[82] G. Pishchulov, A. Trautrims, T. Chesney, S. Gold, and L. Schwab, "The voting analytic hierarchy process revisited: a revised method with application to sustainable supplier selection," International Journal of Production Economics, vol. 211, pp. 166-179, 2019.

[83] Q. Yu and F. Hou, "An approach for green supplier selection in the automobile manufacturing industry," Kybernetes, vol. 45, no. 4, pp. 571-588, 2016.

[84] Z. Xu, J. Qin, J. Liu, and L. Martínez, "Sustainable supplier selection based on AHPSort II in interval type-2 fuzzy environment," Information Sciences, vol. 483, pp. 273-293, 2019.

[85] F. Ecer, "Multi-criteria decision making for green supplier selection using interval type-2 fuzzy AHP: a case study of a home appliance manufacturer," Operational Research, 2020.

[86] M. N. Faisal, B. Al-Esmael, and K. J. Sharif, "Supplier selection for a sustainable supply chain: triple bottom line (3BL) and analytic network process approach," Benchmarking: An International Journal, vol. 24, no. 7, pp. 1956-1976, 2017.

[87] C.-C. Chung, L.-C. Chao, and S.-J. Lou, "The establishment of a green supplier selection and guidance mechanism with the ANP and IPA," Sustainability, vol. 8, no. 3, p. 259, 2016.

[88] C.-W. Hsu and A. H. Hu, "Applying hazardous substance management to supplier selection using analytic network process," Journal of Cleaner Production, vol. 17, no. 2, pp. 255-264, 2009.

[89] G. Büyüközkan and G. Çifçi, “A novel fuzzy multi-criteria decision framework for sustainable supplier selection with incomplete information," Computers in Industry, vol. 62, no. 2, pp. 164-174, 2011.

[90] M. Giannakis, R. Dubey, I. Vlachos, and Y. Ju, "Supplier sustainability performance evaluation using the analytic network process," Journal of Cleaner Production, vol. 247, p. 119439, 2020.

[91] H.-C. Liu, M.-Y. Quan, Z. Li, and Z.-L. Wang, "A new integrated MCDM model for sustainable supplier selection under interval-valued intuitionistic uncertain linguistic environment," Information Sciences, vol. 486, pp. 254-270, 2019.

[92] I. Dobos and G. Vörösmarty, "Inventory-related costs in green supplier selection problems with data envelopment analysis (DEA)," International Journal of Production Economics, vol. 209, pp. 374-380, 2019.

[93] I. Dobos and G. Vörösmarty, "Evaluating green suppliers: improving supplier performance with DEA in the presence of incomplete data," Central European Journal of Operations Research, vol. 27, no. 2, pp. 483-495, 2019.

[94] S. Jafarzadeh Ghoushchi, M. Dodkanloi Milan, and M. Jahangoshai Rezaee, "Evaluation and selection of sustainable suppliers in supply chain using new GP-DEA model with imprecise data," Journal of Industrial Engineering International, vol. 14, no. 3, pp. 613-625, 2018.

[95] N. Zarbakhshnia and T. J. Jaghdani, "Sustainable supplier evaluation and selection with a novel two-stage DEA model in the presence of uncontrollable inputs and undesirable outputs: a plastic case study," International Journal of Advanced Manufacturing Technology, vol. 97, no. 5-8, pp. 2933-2945, 2018.
[96] S. K. Jauhar and M. Pant, "Integrating DEA with DE and MODE for sustainable supplier selection," Journal of Computational Science, vol. 21, pp. 299-306, 2017.

[97] C. N. Wang, V. T. Nguyen, H. T. N. Thai, N. N. Tran, and T. L. A. Tran, "Sustainable supplier selection process in edible oil production by a hybrid fuzzy analytical hierarchy process and green data envelopment analysis for the SMEs food processing industry," Mathematics, vol. 6, no. 12, 2018.

[98] R. J. Kuo and Y. J. Lin, "Supplier selection using analytic network process and data envelopment analysis," International Journal of Production Research, vol. 50, no. 11, pp. 2852-2863, 2012.

[99] R. J. Kuo, Y. C. Wang, and F. C. Tien, "Integration of artificial neural network and MADA methods for green supplier selection," Journal of Cleaner Production, vol. 18, no. 12, pp. 1161-1170, 2010.

[100] M.-C. Yu and M.-H. Su, "Using fuzzy DEA for green suppliers selection considering carbon footprints," Sustainability, vol. 9, no. 4, p. 495, 2017.

[101] S. K. Jauhar and M. Pant, "Sustainable supplier selection: a new differential evolution strategy with automotive industry application," in Studies in Fuzziness and Soft Computing, vol. 342, pp. 353-371, Springer, Berlin, Germany, 2016.

[102] M. Mahdiloo, R. F. Saen, and K.-H. Lee, “Technical, environmental and eco-efficiency measurement for supplier selection: an extension and application of data envelopment analysis," International Journal of Production Economics, vol. 168, pp. 279-289, 2015.

[103] V. Jain, S. Kumar, A. Kumar, and C. Chandra, "An integrated buyer initiated decision-making process for green supplier selection," Journal of Manufacturing Systems, vol. 41, pp. 256-265, 2016.

[104] A. Kumar, V. Jain, S. Kumar, and C. Chandra, "Green supplier selection: a new genetic/immune strategy with industrial application," Enterprise Information Systems, vol. 10, no. 8, pp. 911-943, 2016.

[105] A. Kumar, V. Jain, and S. Kumar, "A comprehensive environment friendly approach for supplier selection," Omega, vol. 42, no. 1, pp. 109-123, 2014.

[106] A. Fallahpour, E. U. Olugu, S. N. Musa, D. Khezrimotlagh, and K. Y. Wong, "An integrated model for green supplier selection under fuzzy environment: application of data envelopment analysis and genetic programming approach," Neural Computing and Applications, vol. 27, no. 3, pp. 707-725, 2016.

[107] P. Shi, B. Yan, S. Shi, and C. Ke, "A decision support system to select suppliers for a sustainable supply chain based on a systematic DEA approach," Information Technology and Management, vol. 16, no. 1, pp. 39-49, 2015

[108] M.-Q. Wu, C.-H. Zhang, X.-N. Liu, and J.-P. Fan, “Green supplier selection based on DEA model in interval-valued Pythagorean fuzzy environment," IEEE Access, vol. 7, pp. 108001-108013, 2019.

[109] M. Izadikhah and R. Farzipoor Saen, "Ranking sustainable suppliers by context-dependent data envelopment analysis," Annals of Operations Research, 2019.

[110] E. A. Bakeshlou, A. A. Khamseh, M. A. G. Asl, J. Sadeghi, and M. Abbaszadeh, "Evaluating a green supplier selection problem using a hybrid MODM algorithm," Journal of Intelligent Manufacturing, vol. 28, no. 4, pp. 913-927, 2017.

[111] M. Khalilzadeh and H. Derikvand, "A multi-objective supplier selection model for green supply chain network under uncertainty," Journal of Modelling in Management, vol. 13, no. 3, pp. 605-625, 2018. 
[112] P. Pandey, B. J. Shah, and H. Gajjar, "A fuzzy goal programming approach for selecting sustainable suppliers," Benchmarking: An International Journal, vol. 24, no. 5, pp. 1138-1165, 2017.

[113] W.-C. Yeh and M.-C. Chuang, "Using multi-objective genetic algorithm for partner selection in green supply chain problems," Expert Systems with Applications, vol. 38, no. 4, pp. 4244-4253, 2011.

[114] C. Bai, S. Kusi-Sarpong, H. Badri Ahmadi, and J. Sarkis, "Social sustainable supplier evaluation and selection: a group decision-support approach," International Journal of Production Research, vol. 57, no. 22, pp. 7046-7067, 2019.

[115] J. Qin, X. Liu, and W. Pedrycz, "An extended TODIM multicriteria group decision making method for green supplier selection in interval type-2 fuzzy environment," European Journal of Operational Research, vol. 258, no. 2, pp. 626-638, 2017.

[116] X. Sang and X. Liu, "An interval type-2 fuzzy sets-based TODIM method and its application to green supplier selection," Journal of the Operational Research Society, vol. 67, no. 5, pp. 722-734, 2016.

[117] A. Arshadi Khamseh and M. Mahmoodi, "A new fuzzy TOPSIS-TODIM hybrid method for green supplier selection using fuzzy time function," Advances in Fuzzy Systems, vol. 2014, Article ID 841405, 10 pages, 2014.

[118] R. Wang and Y. Li, "A novel approach for green supplier selection under a q-rung orthopair fuzzy environment," Symmetry, vol. 10, no. 12, p. 687, 2018.

[119] S. Nie, H. Liao, X. Wu, and Z. Xu, "Green supplier selection with a continuous interval-valued linguistic todim method," IEEE Access, vol. 7, pp. 124315-124328, 2019.

[120] P. Phochanikorn and C. Tan, "An integrated multi-criteria decision-making model based on prospect theory for green supplier selection under uncertain environment: a case study of the Thailand palm oil products industry," Sustainability, vol. 11, no. 7, p. 1872, 2019.

[121] Y. Wu, Y. Ke, C. Xu, and L. Li, “An integrated decisionmaking model for sustainable photovoltaic module supplier selection based on combined weight and cumulative prospect theory," Energy, vol. 181, pp. 1235-1251, 2019.

[122] W. Song, Z. Chen, A. Liu et al., "A study on green supplier selection in dynamic environment," Sustainability, vol. 10, no. 4, p. 1226, 2018.

[123] Z. Guo, H. Liu, D. Zhang, and J. Yang, "Green supplier evaluation and selection in apparel manufacturing using a fuzzy multi-criteria decision-making approach," Sustainability, vol. 9, no. 4, p. 650, 2017.

[124] D. Kannan, K. Govindan, and S. Rajendran, "Fuzzy axiomatic design approach based green supplier selection: a case study from Singapore," Journal of Cleaner Production, vol. 96, pp. 194-208, 2015.

[125] G. Büyüközkan, “An integrated fuzzy multi-criteria group decision-making approach for green supplier evaluation," International Journal of Production Research, vol. 50, no. 11, pp. 2892-2909, 2012.

[126] M. Rabbani, N. Foroozesh, S. M. Mousavi, and H. FarrokhiAsl, "Sustainable supplier selection by a new decision model based on interval-valued fuzzy sets and possibilistic statistical reference point systems under uncertainty," International Journal of Systems Science: Operations \& Logistics, vol. 6, no. 2, pp. 162-178, 2019.

[127] N. Foroozesh, R. Tavakkoli-Moghaddam, and S. M. Mousavi, "An interval-valued fuzzy statistical group decision making approach with new evaluating indices for sustainable supplier selection problem," Journal of Intelligent \& Fuzzy Systems, vol. 36, no. 2, pp. 1855-1866, 2019.

[128] N. Foroozesh, R. Tavakkoli-Moghaddam, and S. Meysam Mousavi, "Sustainable-supplier selection for manufacturing services: a failure mode and effects analysis model based on interval-valued fuzzy group decision-making," International Journal of Advanced Manufacturing Technology, vol. 95, no. 9-12, pp. 3609-3629, 2018.

[129] A. K. Sinha and A. Anand, "Development of sustainable supplier selection index for new product development using multi criteria decision making," Journal of Cleaner Production, vol. 197, pp. 1587-1596, 2018.

[130] M. Yazdani, S. Hashemkhani Zolfani, and E. K. Zavadskas, "New integration of MCDM methods and QFD in the selection of green suppliers," Journal of Business Economics and Management, vol. 17, no. 6, pp. 1097-1113, 2016.

[131] M. Keshavarz Ghorabaee, E. K. Zavadskas, M. Amiri, and A. Esmaeili, "Multi-criteria evaluation of green suppliers using an extended WASPAS method with interval type-2 fuzzy sets," Journal of Cleaner Production, vol. 137, pp. 213-229, 2016.

[132] A. R. Mishra, P. Rani, K. R. Pardasani, and A. Mardani, “A novel hesitant fuzzy WASPAS method for assessment of green supplier problem based on exponential information measures," Journal of Cleaner Production, vol. 238, 2019.

[133] B. Matić, S. Jovanović, D. K. Das et al., "A new hybrid MCDM model: sustainable supplier selection in a construction company," Symmetry, vol. 11, no. 3, p. 353, 2019.

[134] R. Kumari and A. R. Mishra, "Multi-criteria COPRAS method based on parametric measures for intuitionistic fuzzy sets: application of green supplier selection," Iranian Journal of Science and Technology, Transactions of Electrical Engineering, 2020.

[135] M. Shaik and W. Abdul-Kader, "Green supplier selection generic framework: a multi-attribute utility theory approach," International Journal of Sustainable Engineering, vol. 4, no. 1, pp. 37-56, 2011.

[136] Ž. Stević, D. Pamučar, A. Puška, and P. Chatterjee, "Sustainable supplier selection in healthcare industries using a new MCDM method: measurement of alternatives and ranking according to compromise solution (MARCOS)," Computers and Industrial Engineering, vol. 140, Article ID 106231, 2020.

[137] A. Ulutaş, A. Topal, and R. Bakhat, “An application of fuzzy integrated model in green supplier selection," Mathematical Problems in Engineering, vol. 2019, Article ID 4256359, 11 pages, 2019.

[138] Z. Lu, X. Sun, Y. Wang, and C. Xu, "Green supplier selection in straw biomass industry based on cloud model and possibility degree," Journal of Cleaner Production, vol. 209, pp. 995-1005, 2019.

[139] Q. Pang, T. Yang, M. Li, and Y. Shen, "A fuzzy-grey multicriteria decision making approach for green supplier selection in low-carbon supply chain," Mathematical Problems in Engineering, vol. 2017, Article ID 9653261, 9 pages, 2017.

[140] N. K. Sahu, S. Datta, and S. S. Mahapatra, "Green supplier appraisement in fuzzy environment," Benchmarking, vol. 21, no. 3, pp. 412-429, 2014.

[141] A. K. Sinha and A. Anand, "Towards fuzzy preference relationship based on decision making approach to access the performance of suppliers in environmental conscious manufacturing domain," Computers \& Industrial Engineering, vol. 105, pp. 39-54, 2017. 
[142] S. Jafarzadeh Ghoushchi, M. Khazaeili, A. Amini, and E. Osgooei, "Multi-criteria sustainable supplier selection using piecewise linear value function and fuzzy best-worst method," Journal of Intelligent \& Fuzzy Systems, vol. 37, no. 2, pp. 2309-2325, 2019.

[143] Y. Wu, C. Xu, Y. Huang, and X. Li, "Green supplier selection of electric vehicle charging based on Choquet integral and type-2 fuzzy uncertainty," Soft Computing, vol. 24, no. 5, pp. 3781-3795, 2019.

[144] X. Wang, J. Cai, and J. Xiao, "A novel decision-making framework for sustainable supplier selection considering interaction among criteria with heterogeneous information," Sustainability, vol. 11, no. 10, p. 2820, 2019.

[145] J. Zhu and Y. Li, "Green supplier selection based on consensus process and integrating prioritized operator and choquet integral," Sustainability, vol. 10, no. 8, p. 2744, 2018.

[146] A. Shahryari Nia, L. Olfat, A. Esmaeili, R. Rostamzadeh, and J. Antuchevičienè, "Using fuzzy Choquet Integral operator for supplier selection with environmental considerations," Journal of Business Economics and Management, vol. 17, no. 4, pp. 503-526, 2016.

[147] X. G. Xu, H. Shi, F. B. Cui, and M. Y. Quan, "Green supplier evaluation and selection using interval 2-tuple linguistic hybrid aggregation operators," Informatica, vol. 29, no. 4, pp. 801-824, 2019.

[148] Y. Liu, L. Jin, and F. Zhu, "A multi-criteria group decision making model for green supplier selection under the ordered weighted hesitant fuzzy environment," Symmetry, vol. 11, no. 1, p. 17, 2019.

[149] P. Liu, H. Gao, and J. Ma, "Novel green supplier selection method by combining quality function deployment with partitioned Bonferroni mean operator in interval type-2 fuzzy environment," Information Sciences, vol. 490, pp. 292-316, 2019.

[150] S.-L. Tang, "Green supplier selection model with hesitant fuzzy information," Journal of Intelligent \& Fuzzy Systems, vol. 32, no. 1, pp. 189-195, 2017.

[151] S. Yin, B. Li, H. Dong, and Z. Xing, "A new dynamic multicriteria decision-making approach for green supplier selection in construction projects under time sequence," Mathematical Problems in Engineering, vol. 2017, Article ID 7954784, 13 pages, 2017.

[152] K. P. Lin, K. C. Hung, Y. T. Lin, and Y. H. Hsieh, "Green suppliers performance evaluation in belt and road using fuzzy weighted average with social media information," Sustainability, vol. 10, no. 1, p. 5, 2017.

[153] Z. Hu, C. Rao, Y. Zheng, and D. Huang, "Optimization decision of supplier selection in green procurement under the mode of low carbon economy," International Journal of Computational Intelligence Systems, vol. 8, no. 3, pp. 407421, 2015.

[154] J. Fan, X. Jia, and M. Wu, “Green supplier selection based on dombi prioritized bonferroni mean operator with singlevalued triangular neutrosophic sets," International Journal of Computational Intelligence Systems, vol. 12, no. 2, pp. 1091-1101, 2019.

[155] C. H. Chen, "A new multi-criteria assessment model combining GRA techniques with intuitionistic fuzzy entropybased TOPSIS method for sustainable building materials supplier selection," Sustainability, vol. 11, no. 8, p. 2265, 2019.

[156] H. Shi, M.-Y. Quan, H.-C. Liu, and C.-Y. Duan, "A novel integrated approach for green supplier selection with interval-valued intuitionistic uncertain linguistic information: a case study in the agri-food industry," Sustainability, vol. 10, no. 3, p. 733, 2018.

[157] D. K. Sen, S. Datta, and S. S. Mahapatra, "Sustainable supplier selection in intuitionistic fuzzy environment: a decision-making perspective," Benchmarking: An International Journal, vol. 25, no. 2, pp. 545-574, 2018.

[158] N. Banaeian, H. Mobli, B. Fahimnia, I. E. Nielsen, and M. Omid, "Green supplier selection using fuzzy group decision making methods: a case study from the agri-food industry," Computers \& Operations Research, vol. 89, pp. 337-347, 2018.

[159] M. Yazdani, P. Chatterjee, E. K. Zavadskas, and S. Hashemkhani Zolfani, "Integrated QFD-MCDM framework for green supplier selection," Journal of Cleaner Production, vol. 142, pp. 3728-3740, 2017.

[160] M. Tavana, M. Yazdani, and D. Di Caprio, "An application of an integrated ANP-QFD framework for sustainable supplier selection," International Journal of Logistics Research and Applications, vol. 20, no. 3, pp. 254-275, 2017.

[161] A. K. Sahu, S. Datta, and S. S. Mahapatra, "Evaluation and selection of suppliers considering green perspectives: comparative analysis on application of FMLMCDM and fuzzyTOPSIS," Benchmarking: An International Journal, vol. 23, no. 6, pp. 1579-1604, 2016.

[162] H. Kaur, S. P. Singh, and R. Glardon, “An integer linear program for integrated supplier selection: a sustainable flexible framework," Global Journal of Flexible Systems Management, vol. 17, no. 2, pp. 113-134, 2016.

[163] J. Girubha, S. Vinodh, and V. Kek, "Application of interpretative structural modelling integrated multi criteria decision making methods for sustainable supplier selection," Journal of Modelling in Management, vol. 11, no. 2, pp. 358-388, 2016.

[164] C. N. Liao, Y. K. Fu, and L. C. Wu, "Integrated FAHP, ARAS$\mathrm{F}$ and MSGP methods for green supplier evaluation and selection," Technological and Economic Development of Economy, vol. 22, no. 5, pp. 651-669, 2016.

[165] C. Yu, W. Zhao, and M. Li, "An integrated sustainable supplier selection approach using compensatory and noncompensatory decision methods," Kybernetes, vol. 48, no. 8, pp. 1782-1805, 2019.

[166] R.-J. Mao, J.-X. You, C.-Y. Duan, and L.-N. Shao, “A heterogeneous MCDM framework for sustainable supplier evaluation and selection based on the IVIF-TODIM method," Sustainability, vol. 11, no. 18, p. 5057, 2019.

[167] M. O. Okwu and L. K. Tartibu, "Sustainable supplier selection in the retail industry: a TOPSIS- and ANFIS-based evaluating methodology," International Journal of Engineering Business Management, vol. 12, pp. 1-14, 2020.

[168] N. Jain, A. R. Singh, and R. K. Upadhyay, "Sustainable supplier selection under attractive criteria through FIS and integrated fuzzy MCDM techniques," International Journal of Sustainable Engineering, pp. 1-22, 2020.

[169] H. Zhang and Y. Cui, "A model combining a Bayesian network with a modified genetic algorithm for green supplier selection," Simulation, vol. 95, no. 12, pp. 1165-1183, 2019.

[170] J. Sarkis and D. G. Dhavale, "Supplier selection for sustainable operations: a triple-bottom-line approach using a Bayesian framework," International Journal of Production Economics, vol. 166, pp. 177-191, 2015.

[171] I. J. Orji and S. Wei, "An innovative integration of fuzzylogic and systems dynamics in sustainable supplier selection: a case on manufacturing industry," Computers \& Industrial Engineering, vol. 88, pp. 1-12, 2015. 
[172] A. Amindoust and A. Saghafinia, "Textile supplier selection in sustainable supply chain using a modular fuzzy inference system model," Journal of the Textile Institute, vol. 108, no. 7, pp. 1250-1258, 2017.

[173] A. Amindoust, S. Ahmed, A. Saghafinia, and A. Bahreininejad, "Sustainable supplier selection: a ranking model based on fuzzy inference system," Applied Soft Computing, vol. 12, no. 6, pp. 1668-1677, 2012.

[174] G. Qu, R. Xue, T. Li, W. Qu, and Z. Xu, "A stochastic multiattribute method for measuring sustainability performance of a supplier based on a triple bottom line approach in a dual hesitant fuzzy linguistic environment," International Journal of Environmental Research and Public Health, vol. 17, no. 6, p. $2138,2020$.

[175] H. Gao, Y. Ju, E. D. R. Santibanez Gonzalez, and W. Zhang, "Green supplier selection in electronics manufacturing: an approach based on consensus decision making," Journal of Cleaner Production, vol. 245, Article ID 118781, 2020.

[176] W. Ma, W. Lei, and B. Sun, "Three-way group decisions under hesitant fuzzy linguistic environment for green supplier selection," Kybernetes, 2020.

[177] K.-S. Chen, C.-H. Wang, and K.-H. Tan, "Developing a fuzzy green supplier selection model using six sigma quality indices," International Journal of Production Economics, vol. 212, pp. 1-7, 2019.

[178] A. Mohammed, R. Setchi, M. Filip, I. Harris, and X. Li, “An integrated methodology for a sustainable two-stage supplier selection and order allocation problem," Journal of Cleaner Production, vol. 192, pp. 99-114, 2018.

[179] S. Hamdan and A. Cheaitou, "Supplier selection and order allocation with green criteria: an MCDM and multi-objective optimization approach," Computers \& Operations Research, vol. 81, pp. 282-304, 2017.

[180] D. Kannan, R. Khodaverdi, L. Olfat, A. Jafarian, and A. Diabat, "Integrated fuzzy multi criteria decision making method and multi-objective programming approach for supplier selection and order allocation in a green supply chain," Journal of Cleaner Production, vol. 47, pp. 355-367, 2013.

[181] S. Hamdan and A. Cheaitou, "Dynamic green supplier selection and order allocation with quantity discounts and varying supplier availability," Computers \& Industrial Engineering, vol. 110, pp. 573-589, 2017.

[182] V. S. Yadavalli, J. D. Darbari, N. Bhayana, P. C. Jha, and V. Agarwal, "An integrated optimization model for selection of sustainable suppliers based on customers' expectations," Operations Research Perspectives, vol. 6, Article ID 100113, 2019.

[183] K. Govindan and R. Sivakumar, "Green supplier selection and order allocation in a low-carbon paper industry: integrated multi-criteria heterogeneous decision-making and multi-objective linear programming approaches," Annals of Operations Research, vol. 238, no. 1-2, pp. 243-276, 2016.

[184] H.-W. Lo, J. J. H. Liou, H.-S. Wang, and Y.-S. Tsai, “An integrated model for solving problems in green supplier selection and order allocation," Journal of Cleaner Production, vol. 190, pp. 339-352, 2018.

[185] P. Nourmohamadi Shalke, M. M. Paydar, and M. HajiaghaeiKeshteli, "Sustainable supplier selection and order allocation through quantity discounts," International Journal of Management Science and Engineering Management, vol. 13, no. 1, pp. 20-32, 2018.

[186] E. B. Tirkolaee, A. Mardani, Z. Dashtian, M. Soltani, and G.-W. Weber, "A novel hybrid method using fuzzy decision making and multi-objective programming for sustainablereliable supplier selection in two-echelon supply chain design," Journal of Cleaner Production, vol. 250, Article ID 119517, 2020.

[187] A. Mohammed, "Towards a sustainable assessment of suppliers: an integrated fuzzy TOPSIS-possibilistic multi-objective approach," Annals of Operations Research, 2019.

[188] A. Mohammed, I. Harris, and K. Govindan, "A hybrid MCDM-FMOO approach for sustainable supplier selection and order allocation," International Journal of Production Economics, vol. 217, pp. 171-184, 2019.

[189] M. Almasi, S. Khoshfetrat, and M. Rahiminezhad Galankashi, "Sustainable supplier selection and order allocation under risk and inflation condition," IEEE Transactions on Engineering Management, pp. 1-15, 2020.

[190] K. Shaw, R. Shankar, S. S. Yadav, and L. S. Thakur, "Supplier selection using fuzzy AHP and fuzzy multi-objective linear programming for developing low carbon supply chain," Expert Systems with Applications, vol. 39, no. 9, pp. 81828192, 2012.

[191] S. Khoshfetrat, M. Rahiminezhad Galankashi, and M. Almasi, "Sustainable supplier selection and order allocation: a fuzzy approach," Engineering Optimization, 2019.

[192] T. Laosirihongthong, P. Samaranayake, and S. Nagalingam, "A holistic approach to supplier evaluation and order allocation towards sustainable procurement," Benchmarking: An International Journal, vol. 26, no. 8, pp. 2543-2573, 2019.

[193] N. Banaeian, H. Mobli, I. E. Nielsen, and M. Omid, “Criteria definition and approaches in green supplier selection-a case study for raw material and packaging of food industry," Production \& Manufacturing Research, vol. 3, no. 1, pp. 149-168, 2015.

[194] A. Cheraghalipour and S. Farsad, "A bi-objective sustainable supplier selection and order allocation considering quantity discounts under disruption risks: a case study in plastic industry," Computers \& Industrial Engineering, vol. 118, pp. 237-250, 2018.

[195] C. Babbar and S. H. Amin, "A multi-objective mathematical model integrating environmental concerns for supplier selection and order allocation based on fuzzy QFD in beverages industry," Expert Systems with Applications, vol. 92, pp. 27-38, 2018.

[196] A. Arabsheybani, M. M. Paydar, and A. S. Safaei, "An integrated fuzzy MOORA method and FMEA technique for sustainable supplier selection considering quantity discounts and supplier's risk," Journal of Cleaner Production, vol. 190, pp. 577-591, 2018.

[197] S.-Y. You, L.-J. Zhang, X.-G. Xu, and H.-C. Liu, "A new integrated multi-criteria decision making and multi-objective programming model for sustainable supplier selection and order allocation," Symmetry, vol. 12, no. 2, p. 302, 2020.

[198] C.-Y. Duan, H.-C. Liu, L.-J. Zhang, and H. Shi, “An extended alternative queuing method with linguistic Z-numbers and its application for green supplier selection and order allocation," International Journal of Fuzzy Systems, vol. 21, no. 8, pp. 2510-2523, 2019.

[199] H. G. Gören, "A decision framework for sustainable supplier selection and order allocation with lost sales," Journal of Cleaner Production, vol. 183, pp. 1156-1169, 2018.

[200] K. Park, G. E. Okudan Kremer, and J. Ma, "A regional information-based multi-attribute and multi-objective decision-making approach for sustainable supplier selection and order allocation," Journal of Cleaner Production, vol. 187, pp. 590-604, 2018. 
[201] H. Moheb-Alizadeh and R. Handfield, "Sustainable supplier selection and order allocation: a novel multi-objective programming model with a hybrid solution approach," Computers \& Industrial Engineering, vol. 129, pp. 192-209, 2019.

[202] A. Torres Ruiz and A. Ravindran, "Multiobjective optimisation model for the selection of critical suppliers integrating sustainability criteria," International Journal of Operational Research, vol. 33, no. 2, pp. 208-238, 2018.

[203] H. Moheb-Alizadeh and R. Handfield, "An integrated chance-constrained stochastic model for efficient and sustainable supplier selection and order allocation," International Journal of Production Research, vol. 56, no. 21, pp. 6890-6916, 2018.

[204] F. Vahidi, S. A. Torabi, and M. J. Ramezankhani, "Sustainable supplier selection and order allocation under operational and disruption risks," Journal of Cleaner Production, vol. 174, pp. 1351-1365, 2018.

[205] J. S. Kim, E. Jeon, J. Noh, and J. H. Park, "A model and an algorithm for a large-scale sustainable supplier selection and order allocation problem," Mathematics, vol. 6, no. 12, p. 325, 2018.

[206] W.-H. Tsai and S.-J. Hung, “A fuzzy goal programming approach for green supply chain optimisation under activitybased costing and performance evaluation with a value-chain structure," International Journal of Production Research, vol. 47, no. 18, pp. 4991-5017, 2009.

[207] R. Jia, Y. Liu, and X. Bai, "Sustainable supplier selection and order allocation: distributionally robust goal programming model and tractable approximation," Computers \& Industrial Engineering, vol. 140, Article ID 106267, 2020.

[208] M. Rabieh, A. F. Rafsanjani, L. Babaei, and M. Esmaeili, "Sustainable supplier selection and order allocation: an integrated delphi method, fuzzy TOPSIS, and multi-objective programming model," Scientia Iranica, vol. 26, no. 4E, pp. 2524-2540, 2019.

[209] E. KhanMohammadi, H. Talaie, H. Safari, and R. Salehzadeh, "Supplier evaluation and selection for sustainable supply chain management under uncertainty conditions," International Journal of Sustainable Engineering, vol. 11, no. 6, pp. 382-396, 2018.

[210] Y. Liang, J. Liu, J. Qin, and Y. Tu, "An improved multigranularity interval 2-Tuple TODIM approach and its application to green supplier selection," International Journal of Fuzzy Systems, vol. 21, no. 1, pp. 129-144, 2019.

[211] J. Wang, J.-q. Wang, Z.-p. Tian, and D.-y. Zhao, "A multihesitant fuzzy linguistic multicriteria decision-making approach for logistics outsourcing with incomplete weight information," International Transactions in Operational Research, vol. 25, no. 3, pp. 831-856, 2018. 